\title{
Activation of the EIF2 $\alpha /$ ATF4 and ATF6 Pathways in DU-145 Cells by Boric Acid at the Concentration Reported in Men at the US Mean Boron Intake
}

\author{
Sarah E. Kobylewski ${ }^{1} \cdot$ Kimberly A. Henderson $^{1}$. \\ Kristin E. Yamada $^{1}$ - Curtis D. Eckhert ${ }^{1,2}$ \\ Received: 19 July 2016 / Accepted: 15 August 2016 /Published online: 1 September 2016 \\ (C) The Author(s) 2016. This article is published with open access at Springerlink.com
}

\begin{abstract}
Fruits, nuts, legumes, and vegetables are rich sources of boron (B), an essential plant nutrient with chemopreventive properties. Blood boric acid (BA) levels reflect recent $B$ intake, and men at the US mean intake have a reported non-fasting level of $10 \mu \mathrm{M}$. Treatment of DU-145 prostate cancer cells with physiological concentrations of BA inhibits cell proliferation without causing apoptosis and activates eukaryotic initiation factor 2 (eIF2 $\alpha$ ). EIF2 $\alpha$ induces cell differentiation and protects cells by redirecting gene expression to manage endoplasmic reticulum stress. Our objective was to determine the temporal expression of endoplasmic reticulum (ER) stress-activated genes in DU-145 prostate cells treated with $10 \mu \mathrm{M}$ BA. Immunoblots showed post-treatment increases in eIF $2 \alpha$ protein at 30 min and ATF4 and ATF6 proteins at $1 \mathrm{~h}$ and $30 \mathrm{~min}$, respectively. The increase in ATF4 was accompanied by an increase in the expression of its downstream genes growth arrest and DNA damage-induced protein 34 (GADD34) and homocysteine-induced ER protein (Herp), but a decrease in GADD153/CCAAT/enhancer-binding protein homologous protein (CHOP), a pro-apoptotic gene. The increase in ATF6 was accompanied by an increase in
\end{abstract}

Electronic supplementary material The online version of this article (doi:10.1007/s12011-016-0824-y) contains supplementary material, which is available to authorized users.

Curtis D. Eckhert

ceckhert@ucla.edu

Interdepartmental Program in Molecular Toxicology, University of California, Los Angeles, CA, USA

2 Department of Environmental Health Sciences, University of California, Fielding School of Public Health, 650 Charles E. Young Dr., Los Angeles, CA 90095, USA expression of its downstream genes GRP78/BiP, calreticulin, Grp94, and EDEM. BA did not activate IRE1 or induce cleavage of XBP1 mRNA, a target of IRE1. Low boron status has been associated with increased cancer risk, low bone mineralization, and retinal degeneration. ATF4 and BiP/GRP78 function in osteogenesis and bone remodeling, calreticulin is required for tumor suppressor $\mathrm{p} 53$ function and mineralization of teeth, and BiP/GRP78 and EDEM prevent the aggregation of misfolded opsins which leads to retinal degeneration. The identification of BA-activated genes that regulate its phenotypic effects provides a molecular underpinning for boron nutrition and biology.

Keywords ATF4 - ATF6A · Boric acid · Boron · Calreticulin $(\mathrm{CALR}) \cdot \mathrm{EDEM} 1 \cdot \mathrm{eIF} 2 \alpha(\mathrm{EIF} 2 \mathrm{~A}) \cdot \mathrm{GADD} 34$ (PPP1R15A) · GADD153/CHOP (DDIT3) · GRP78/BiP (HSPa5) · GRP94 (HSP90B1) · Herp (HERPUD1) · Hrd1 $(\mathrm{SYVN1}) \cdot \mathrm{RE} 1(\mathrm{ERN1}) \cdot \mathrm{XBP} 1 \cdot \mathrm{DU}-145 \cdot$ Nutrition
Abbreviations
$B A \quad$ Boric acid
$c A D P R \quad$ Cyclic ADP ribose
ER Endoplasmic reticulum
$U P R \quad$ Unfolded protein response
GADD34 Growth arrest and DNA damage-inducible pro- tein 34
HERP Homocysteine-responsive endoplasmic reticulum resident ubiquitin-like domain member 1 protein
CHOP CCAAT/enhancer-binding protein homologous protein
GRP78 Binding immunoglobulin protein (BiP) (also known as 78-kDa glucose-regulated protein)
GRP94 94-kDa glucose-regulated (also known as protein heat shock protein $90-\mathrm{kDa}$ beta member 1) 
XBP-1

Xbox binding protein

EDEM1 ER degradation enhancer mannosidase alpha-like 1

mRNP Ribonuclear protein particles

ATF4 Activating transcription factor 4

ISR Integrated stress response

ESRE1 Endoplasmic reticulum stress response element 1
Methods

\section{Chemical}

DMSO, DTT, boric acid, $\mathrm{NaCl}$, Tris, methanol, $\mathrm{MgCl}_{2}$, sucrose, and methanol were purchased from Sigma-Aldrich (St. Louis, MO). Triton X-100, Tween-20, NP40, and cycloheximide were purchased from Fisher Scientific (Pittsburg, PA). Paraformaldehyde was purchased from Affymetrix/USB Corporation (Cleveland, $\mathrm{OH}$ ). Thapsigargin and BSA were purchased from Santa Cruz Biotechnology (Santa Cruz, CA). Phosphatase inhibitors and protease were purchased from Calbiochem (San Diego, CA), and fetal bovine serum (FBS) was purchased from Gibco-Life Sciences (Grand Island, NY).

\section{Cell Culture}

DU-145 prostate cancer cells were purchased from the American Type Culture Collection (Manassas, VA) and subcultured at a ratio of 1:6 and used for seven passages. The ATCC description of the DU-145 karyotype is given in Supplement 2 [24]. DU-145 is included in the COSMIC Cell Line Project, and available information for each gene measured in this paper is given in Tables 1-6 of Supplement 2. The cell culture medium was RPMI-1640 Medium (GibcoLife Technologies, Grand Island, NY) supplemented with $10 \%$ FBS, L-glutamine $(200 \mathrm{mM})$, streptomycin $(100 \mu \mathrm{g} /$ $\mathrm{mL})$, and penicillin $(100 \mathrm{U} / \mathrm{mL})$ (Gemini Bio Products, Sacramento, CA). Cells were plated on 10- or $15-\mathrm{cm}$ plates (Corning Life Sciences, Corning, NY) and incubated in a humidified chamber at $37{ }^{\circ} \mathrm{C}$ and $5 \% \mathrm{CO}_{2}$ and $95 \%$ air to $80 \%$ confluency. Media used for all treatment groups were first stripped of boron by shaking with $2 \mathrm{~g}$ of Amberlite IRA 743 exchange resin (Sigma-Aldrich) for $12 \mathrm{~h}$ at $4{ }^{\circ} \mathrm{C} . \mathrm{H}_{2} \mathrm{O}$ or BA $(10 \mathrm{mM})$ was added respectfully to prepare untreated and $10 \mu \mathrm{M}$ BA cell culture media [25]. Cells were cultured in untreated media until $80 \%$ confluency and sub-cultured for experiments using untreated media or media adjusted to $10 \mu \mathrm{M}$ BA.

\section{Polysome Profile}

Polysome profiles were developed from untreated and BAtreated cells obtained from paired culture plates and processed in parallel. Plated cells were incubated in culture media containing $50 \mu \mathrm{g} / \mathrm{mL}$ cycloheximide for $10 \mathrm{~min}$ at $37^{\circ} \mathrm{C}$. Plates were then chilled on ice, the media removed, and cells were rinsed two to three times with ice-cold PBS containing $50 \mu \mathrm{g} /$ $\mathrm{mL}$ cycloheximide. The cells were lysed in $500 \mu \mathrm{l}$ lysis buffer (20 mM Tris (pH 7.5), $100 \mathrm{mM} \mathrm{NaCl}, 10 \mathrm{mM} \mathrm{MgCl} 2,0.4 \%$ NP-40, $50 \mu \mathrm{g} / \mathrm{mL}$ cycloheximide, and protease and phosphatase inhibitors. The lysate was scraped with a spatula response of genes in the ER stress pathways. 
(Corning) and transferred to a microcentrifuge tube. The lysate was passed through a sterile 23-gauge needle (BD, Franklin Lakes, NJ) 8-10 times and incubated on ice for $10 \mathrm{~min}$. The lysate was centrifuged at $8000 \times \mathrm{g}$ for $10 \mathrm{~min}$, and the supernatant was used for the polysome profile. The gradient was prepared by filling a SW41 centrifuge tube approximately halfway with $10 \%$ gradient solution $[20 \mathrm{mM}$ Tris- $\mathrm{HCl}$, pH 7.5, $100 \mathrm{mM} \mathrm{NaCl}, 5 \mathrm{mM} \mathrm{MgCl} 2,0.5 \mathrm{mM}$ DTT, $0.1 \mathrm{mg} / \mathrm{mL}$ cycloheximide, and $10 \%$ sucrose $(w / v)]$. A 23-gauge needle was used to add solution containing $20 \mathrm{mM}$ Tris- $\mathrm{HCl}, \mathrm{pH} 7.4,100 \mathrm{mM} \mathrm{NaCl}, 5 \mathrm{mM} \mathrm{MgCl}$, $0.5 \mathrm{mM}$ DTT, $0.1 \mathrm{mg} / \mathrm{mL}$ cycloheximide, and $50 \%(\mathrm{v} / \mathrm{w})$ sucrose to the bottom of the tube to form the lower layer. A gradient maker was used to create a $10-50 \%$ gradient. Lysate with OD of 10 (up to $800 \mu \mathrm{l}$ ) was gently added to the top of the gradient. The tubes were balanced, gently placed in a precooled SW41 rotor (Beckman Coulter, Brea, CA), and centrifuged for $3 \mathrm{~h}$ at $35,000 \mathrm{rpm}$. Fifty fractions were collected through a 23-gauge needle inserted through the bottom of the tube and immediately placed on ice. The absorbance of each fraction was measured at $254 \mathrm{~nm}$. Monosomes and polysomes were quantified by measuring the area under the $80 \mathrm{~S}$ monosomal peak and the area under the polysomes using the trapezoidal area under the curve method.

\section{Immunoblot Analysis}

DU-145 cells were grown to $80 \%$ confluency on $15-\mathrm{cm}$ plates (Corning) and treated with $10 \mu \mathrm{M} \mathrm{BA}, 1 \mu \mathrm{M}$ thapsigargin, or DMSO positive control vehicle for various times. Cells were washed with ice-cold phosphate buffer solution (PBS) supplemented with $0.1 \%$ Tween (PBST) and treated with $100 \mu \mathrm{l}$ radioimmunoprecipitation assay (RIPA) lysis buffer. Actin and GAPDH were used as loading controls and selected based on their molecular mass band separation from the protein of interest. Cells were scraped from plates using a spatula (Corning) placed on ice, and the lysate was passed through a 23 -gauge needle (BD) 8-10 times. The protein was quantitated using Coomassie Plus Protein Assay (Thermo-Scientific, Waltham, MA). Aliquots containing 30-35 $\mu$ g protein sample were separated using a 4-12\% gradient TGX SDS-PAGE (Bio-Rad, Hercules, CA) at $200 \mathrm{~V}$ for $30 \mathrm{~min}$. Protein was transferred to a nitrocellulose membrane using a transfer buffer containing $20 \%$ methanol at $40 \mathrm{~V}$ for $1.5 \mathrm{~h}$. Membranes were blocked in $3 \%$ BSA with $37.5 \mathrm{mM}$ Tris (pH 8.8), $0.1 \%$ Tween 20 , and $125 \mathrm{mM} \mathrm{NaCl}$ for at least $4 \mathrm{~h}$. Antibodies were selected from commercial suppliers based on their specificity for human orthologs and validated by comparison of immunoblot bands to standard molecular mass ladders (Bio-Rad). Antibody dilutions were selected based on testing of lots prior to use in experiments and ranged from 1:200 to 1:1000. Blocked membranes were incubated with the primary antibody for $1 \mathrm{~h}$ in PBST or $3 \%$ BSA blocking solution and washed in PBST. They were then incubated with a secondary antibody with an HRP tag, followed by washing three times with PBST. The membranes were exposed to ECL Plus (Amersham/GE Healthcare, Pittsburg, PA) for 2-5 min and imaged using a Typhoon 9410 Variable Mode Imager (Amersham). Densitometry was performed using ImageQuant 5.2 software (Molecular Dynamics, Pittsburg, PA). All secondary antibodies were purchased from Santa Cruz Biotechnologies (Santa Cruz, CA). The following primary antibodies from Santa Cruz Biotechnology were used: GRP78/BiP (mouse monoclonal), Actin (goat polyclonal), GAPDH (mouse monoclonal), ATF4 (rabbit polyclonal), GADD34 (rabbit polyclonal), CHOP/Gadd153 (rabbit polyclonal), XBP-1 (rabbit polyclonal), and ATF6 $\alpha$ (rabbit polyclonal). The eIF $2 \alpha$ (rabbit polyclonal) and ph-eIF $2 \alpha$ (rabbit polyclonal) antibodies were purchased from Cell Signaling (Danvers, MA), and ATF6 (mouse monoclonal) was purchased from Imgenex (San Diego, CA).

\section{TaqMan Real-Time PCR}

DU-145 cells were grown on 10 -cm plates (Corning) to $80 \%$ confluency at least $24 \mathrm{~h}$ prior to treatment. Cells were treated with $10 \mu \mathrm{M}$ BA, $1 \mu \mathrm{M}$ thapsigargin, or DMSO vehicle for varying time points. RNA was isolated from cells at indicated time points $(0,0.25,0.5,1,2,3,4,5,6,12$, or $24 \mathrm{~h})$ using an RNeasy Mini Kit (Qiagen, Valencia, CA). Total RNA $(2 \mu \mathrm{g})$ was reverse transcribed using Superscript III Reverse Transcriptase (Invitrogen) with random hexamer primers (Invitrogen) at a final volume of $20 \mu \mathrm{l}$ at $25{ }^{\circ} \mathrm{C}, 10 \mathrm{~min}$ (10:00); $50{ }^{\circ} \mathrm{C}, 45: 00$; and $70{ }^{\circ} \mathrm{C}, 15: 00$. Applied Biosystems (ABI, Foster City, CA) TaqMan pre-designed assays were used for all genes as well as GAPDH as a control internal housekeeping gene. Plates were read by a 7500 Fast Real-Time PCR System using the 7500 Fast System Software v1.4.0 (ABI). Quantitation of gene expression levels was calculated from a standard curve created from reactions containing a combination of complementary DNA (cDNA) from all treatments for each gene.

\section{Immunofluorescent Microscopy}

DU-145 cells were grown to $80 \%$ confluency on glass coverslips (Fisher Scientific, Pittsburg, PA) and treated with either BA-free media, $10 \mu \mathrm{M}$ BA, or $1 \mu \mathrm{M}$ thapsigargin. Antibodies were tested on immunoblots of lysed cells prior to using them for immunohistochemistry. Cells stained for ATF 6 were first fixed with $4 \%$ paraformaldehyde in PBS and permeabilized with $0.5 \%$ Triton $\mathrm{X}-100$ in PBS. Fixed cells were blocked with $10 \%$ FBS in PBS overnight. The next day, they were moved to a humidity chamber and incubated with anti-ATF6 (Imgenex, San Diego, CA) monoclonal antibody at a 
concentration of 1:50, followed by secondary Alexa 488 or FITC at 1:100. Coverslips were mounted with a mixture of Vectashield with 4',6-diamidino-2-phenylindole (Vector Laboratories, Burlingame, CA) and regular Vectashield HardSet (Vector Laboratories) mounting mediums at 1:5. Images were captured with an Olympus DP72 camera (Olympus America, Center Valley, PA) connected to an Olympus BX51 fluorescence microscope (Olympus America) using an Olympus UIS2 UPlanFLN 100X/1.30 OilPh3 objective (Olympus America) and FITC and DAPI filters. Olympus DP2-BSW (Olympus America) or Adobe Photoshop (Adobe Systems Incorporated, San Jose, CA) software was used to merge and crop images.

\section{XBP1 Cleavage Analysis}

Total RNA was extracted from BA $(0-250 \mu \mathrm{M})$-treated or thapsigargin $(10 \mu \mathrm{M})$-treated DU-145 cells using RNeasy Mini Kit (Qiagen). RNA was reverse transcribed using SuperScript III Reverse Transcriptase (Invitrogen). XBP1 cDNA was amplified with GoTaq Flexi DNA Polymerase (Promega, Madison WI) using the forward primer 5'CACCTGAGCCCCGAGGAG-3' and reverse primer 5'TTAGTTCATTAATGGCTTCCAGC-3' [HGNC:12801; NCBI Reference Sequence: NM_005080.3]. Fifty-microliter PCR reactions were run under the following amplification conditions: $95^{\circ} \mathrm{C}$ for $2 \mathrm{~min} ; 95^{\circ} \mathrm{C}$ for $30 \mathrm{~s}, 60{ }^{\circ} \mathrm{C}$ for $30 \mathrm{~s}$, $72^{\circ} \mathrm{C}$ for $30 \mathrm{~s}$, all for 25 cycles; and $72^{\circ} \mathrm{C}$ for $5 \mathrm{~min}$ [26]. PCR products were run on $2 \%$ agarose E-gels with SYBR Safe (Invitrogen) or $4 \%$ ethidium bromide agarose gels (Fig. 11).

\section{Statistical Analysis}

SigmaStat 3.1 (Systat Software, Point Richmond, CA) was used for analysis of data and selection of appropriate statistical tests. Results of the statistical analysis for each figure are provided in Supplement 1 Polysome profiles were developed from untreated and BA-treated cells obtained from paired culture plates processed in parallel. Monosomes and polysomes were quantified by measuring the area under the $80 \mathrm{~S}$ monosomal peak and the area under the polysomes using the trapezoidal area under the curve method. The difference in means of polysome/ monosome ratios from three independent experiments run on different days was evaluated using a paired $t$ test. Replicates of data in Figs. 2, 3, 4, 5, 6, 7, 8, 9, 10, 11, and 12 represent cells plated from different seedings on different days. Analysis of timed studies used a one-way repeated measures analysis of variance to determine the effect of treatment time. Differences between the mean at pre-treatment time zero (control) and means at posttreatment time points were evaluated using the Holm-
Sidak multiple comparison test. The number of replicates for each significant time point is given in the figure legends and Supplement 1. ImageJ software (NIH, Bethesda, MD) was used for immunofluorescence quantitation of stained cells. Only cells with clear borders of the ER and nucleus were selected for study. Mean intensity of nuclear and cytoplasmic areas of identical size was determined using the histogram tool in RGB mode. For ATF6 images, the polygon tool was used to trace the outer edges of the FITC and DAPI-stained areas and the ER was calculated by subtracting the area of the DAPI from the area of the FITC. Proof that DU-145 cells were capable of activating the genes under study was obtained by treatment with $1 \mu \mathrm{M}$ thapsigargin, a strong inducer of ER stress that activates apoptosis [27]. The statistical significance of thapsigargin treatment in Figs. 2, 3, 4, 6, 8, 9, 10 , and 12 was compared to treatment with its solvent DMSO using a $t$ test.

\section{Availability of Supporting Data}

Supplement 1 contains tables of statistical evaluations of the data for each figure. Supplement 2 gives the ATCC karyotype description of DU-145 and mutation status of genes available in COSMIC and Ensemble in Tables 1-6 [28].

\section{Results}

\section{BA Causes a Decrease in the Polysome/Monosome Ratio}

Environmental conditions that stress ER function elicit a response that inhibits global translation and selectively enhances the transcription and translation of proteins needed to alleviate the stress [29]. Transcripts that are not translated form ribonuclear protein particles (mRNP) that sediment at $20 \mathrm{~S}$ to $35 \mathrm{~S}$. Messenger RNAs (mRNAs) that are translated accumulate as $80 \mathrm{~S}$ monosomes composed of small (40S) and large (60S) ribosomal subunits that travel along the mRNA during translational elongation. During protein synthesis, many monosomes can initiate translation on a single mRNA transcript to form a polyribosome or polysome. Polysomes disassemble under environmental conditions that inhibit protein synthesis, and this results in a decrease in the polysome/monosome ratio $[30,31]$. We measured the areas under the $80 \mathrm{~S}$ monosomal peak and polysomes using the trapezoidal area under the curve method. We show that treatment of DU-145 cells with $10 \mu \mathrm{M}$ BA reduced the polysome/ monosome ratio by approximately $54 \%$, demonstrating that protein translation was significantly inhibited, but not stopped (Fig. 1, Supplement 1). 

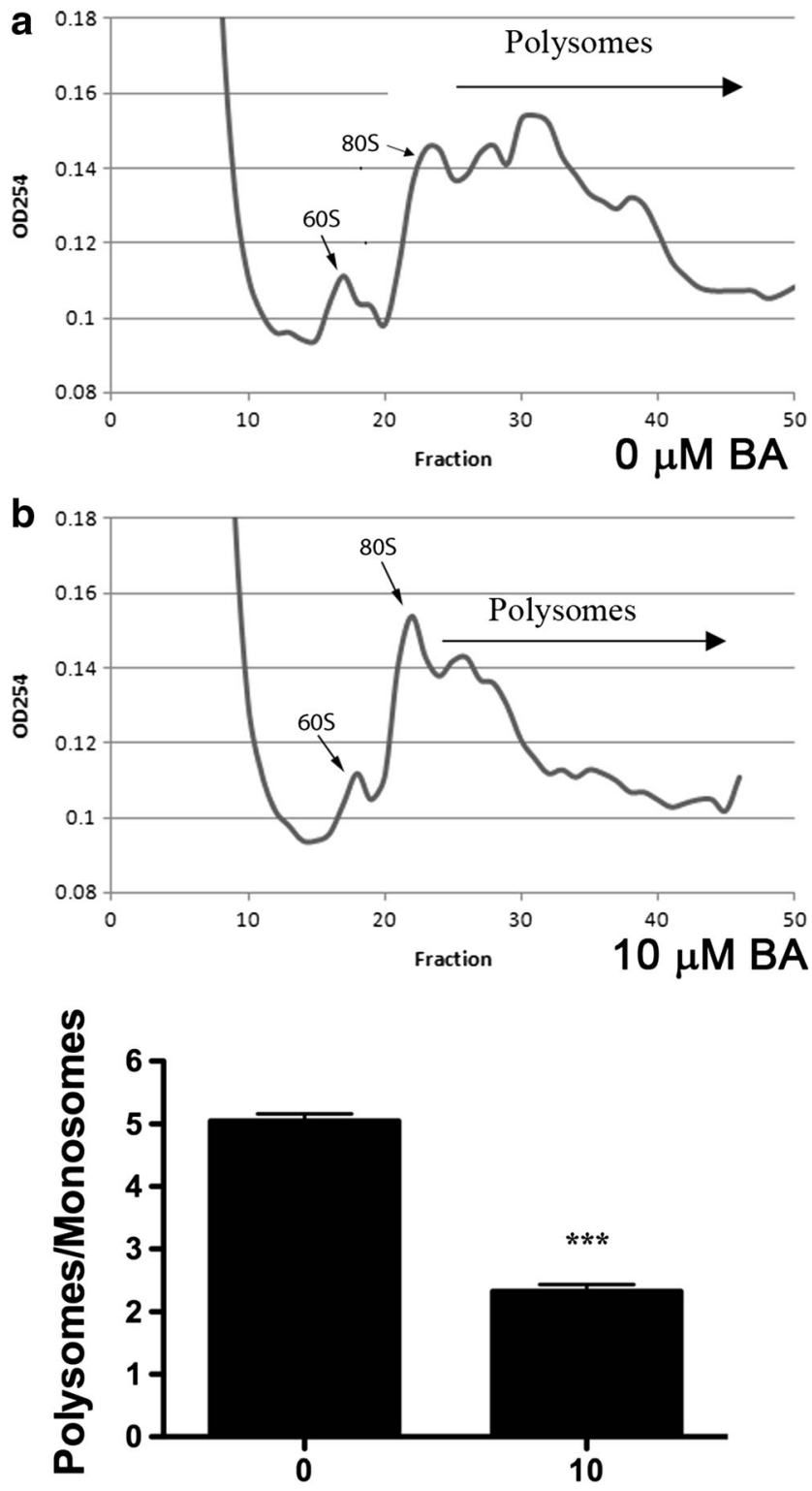

Boric Acid $(\mu \mathrm{M})$

Fig. 1 BA induces a lower polysome/monosome ratio in DU-145 cells indicating a reduction in global protein translation. DU-145 cells treated with $10 \mu \mathrm{M} \mathrm{BA}$ for $2 \mathrm{~h}$ (a) had a significantly lower polysome/ monosome ratio than did DU-145 cells treated with $0 \mu \mathrm{M}$ BA for $2 \mathrm{~h}$ (b). Polysomes from untreated and BA-treated cells were obtained from cells treated in parallel using paired culture plates and centrifuging together in the same rotor. Figure shows a representative replicate. The difference in polysome/monosome ratios from three independent experiments was evaluated using a paired $t$ test $(p<0.001, n=3)$

\section{BA Induces Phosphorylation of eIF2 $\alpha$}

The eIF2 complex is part of a large ternary complex (eIF2-GTP-tRNAi Met) that positions the initiator methionine at the first codon of mRNA to commence translation and protein synthesis. eIF $2 \alpha$ is the regulatory subunit of the eIF2 complex, and phosphorylation on serine 51 inhibits the formation of the eIF2-GTP-tRNAi Met complex preventing the initiation of translation [32]. We measured phosphorylation of eIF $2 \alpha$ at serine 51 in DU-145 cells treated with $10 \mu \mathrm{M}$ BA. The proportion of eIF $2 \alpha$ phosphorylated (eIF $2 \alpha$ phosphorylation/total eIF $2 \alpha$ ) was mildly but significantly increased following $0.5,1$, and $2 \mathrm{~h}$ of treatment (Fig. 2a). The maximum increase in phosphorylation was $125 \%$ at 60 min after BA treatment. As a positive control, we treated DU-145 cells with $1 \mu \mathrm{M}$ thapsigargin or DMSO (vehicle) for $1 \mathrm{~h}$. Thapsigargin, a strong inducer of ER stress [27], significantly induced phosphorylation of eIF2 $\alpha$ in DU-145 cells (Fig. 2b).

\section{BA Induces GADD34 Transcription and Translation}

GADD34 associates with protein phosphatase 1 and promotes dephosphorylation of eIF $2 \alpha$ [33]. BA treatment resulted in a maximum increase in mRNA of $125 \%$ at $2 \mathrm{~h}$ and increase of protein of $53 \%$ at $2 \mathrm{~h}$ (Figs. 7a and 3a, Table 1). Treatment with thapsigargin also increased GADD34 protein (Fig. 3b).

\section{BA Increases GRP78/BiP Transcription and Translation}

Glucose-regulated protein (GRP78/BiP) is a major $\mathrm{Ca}^{2+}$ binding protein in the ER and binds to and maintains the three unfolded protein response (UPR) transmembrane sensors ATF6, PERK, and IRE1 in an inactive form $[34,35]$. We measured GRP78/BiP in DU-145 cells treated with $10 \mu \mathrm{M}$ BA. The maximum increase of mRNA was $149 \%$ at $30 \mathrm{~min}$ and of protein $98 \%$ at $60 \mathrm{~min}$ following BA treatment (Figs. 10a and 4a, Table 1). DU-145 cells treated with thapsigargin also increased GRP78/BiP protein (Fig. 4b).

\section{BA Induces ATF4 Transcription and Translation}

Phosphorylation of eIF $2 \alpha$ selectively activates transcription and translation of ATF4, a transcription factor in the highly conserved integrated stress response (ISR) that enables cells to survive in adverse environmental conditions. We used RT-PCR to measure ATF4 transcription in DU145 cells treated with $10 \mu \mathrm{M}$ BA. ATF4 mRNA was increased at 1 and $2 \mathrm{~h}$ post-treatment (Fig. 5). The maximum increase in mRNA was $46 \%$ at $2 \mathrm{~h}$ after BA treatment (Table 1). ATF4 mRNA was also elevated in cells treated with thapsigargin (Fig. 5). ATF4 protein was significantly increased from 1 to $3 \mathrm{~h}$ followed by a decrease at $5 \mathrm{~h}$ post-treatment (Fig. 6a). The maximum increase was $53 \%$ at $3 \mathrm{~h}$ (Fig. 6a, Table 1). Thapsigargin treatment also increased ATF4 protein levels (Fig. 6b). 


\section{BA Induces GADD34 and Herp but Decreases CHOP Transcription}

ATF4 moves into the nucleus where it activates genes that either assist in cell survival by relieving ER stress or promote apoptosis in the case of lethal stresses [36]. GADD34 and homocysteine-induced ER protein (Herp) are ATF4-inducible survival genes, and CHOP (GADD153), which is also induced by ATF4, is a proapoptotic gene. We treated DU-145 cells with $10 \mu \mathrm{M}$ BA and used RT-PCR to analyze changes in mRNA levels. GADD34, which provides a negative feedback loop in the eIF $2 \alpha /$ ATF 4 pathway by dephosphorylating
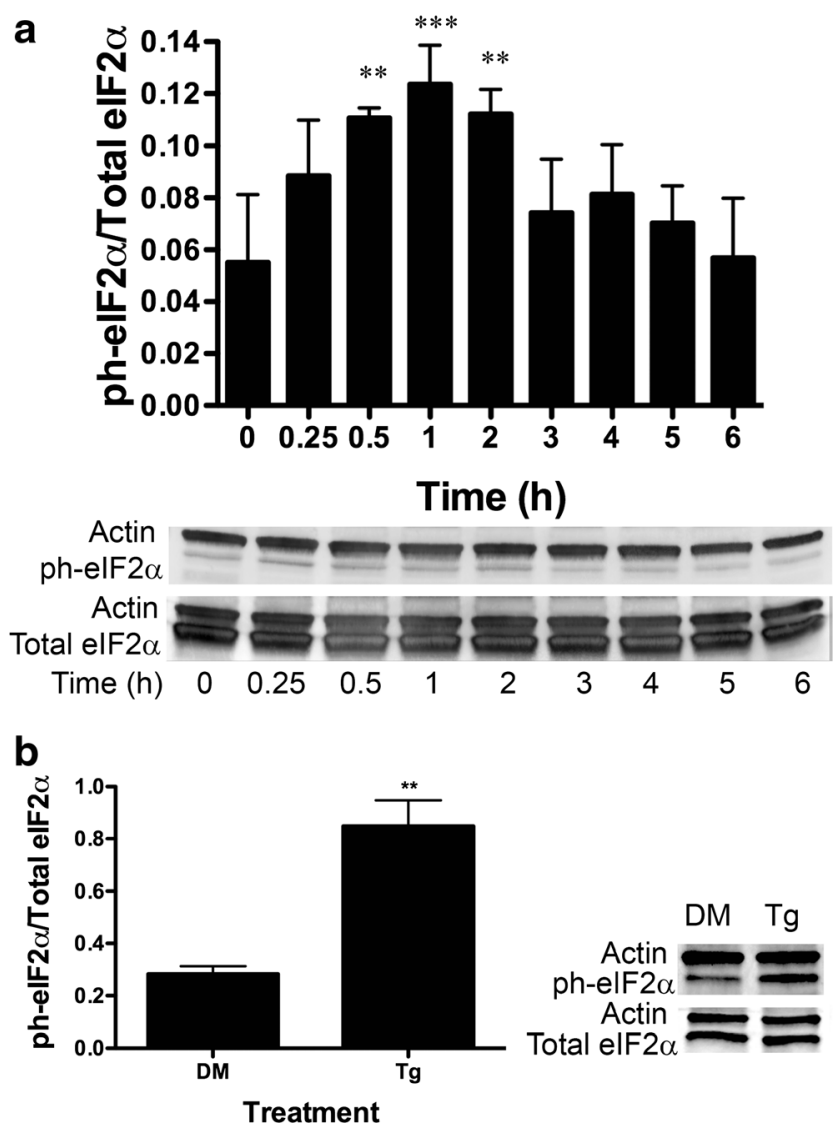

Fig. 2 BA induces eIF $2 \alpha$ phosphorylation at ser-51 in DU-145 cells. a DU-145 cells were treated with $10 \mu \mathrm{M}$ BA for $0,0.25,0.5,1,2,3,4,5$, and $6 \mathrm{~h}$. Phosphorylation of eIF $2 \alpha$ was significantly higher at 0.5 $(p<0.006, n=3), 1,(p<0.001, n=3)$, and $2 \mathrm{~h}(p<0.005, n=3)$ post-treatment. b DU-145 cells were treated with $1 \mu \mathrm{M}$ thapsigargin (Tg), a strong positive control that induces stress and apoptosis, or DMSO (DM), the vehicle for $\mathrm{Tg}$ for $1 \mathrm{~h}, p<0.01, n=3$. In Figs. 2, 3, 4, 5, 6, $7,8,9,10,11$, and 12 , the probabilities of statistical differences are represented as $* p<0.05,{ }^{*} p<<0.01$, and $* * * p<0.001$. Gels shown in Figs. 2, 3, 4, 5, 6, 7, 8, 9, 10, 11, and 12 are a representative replicates of timed studies. Timed study data were analyzed using a one-way repeated measures analysis of variance (ANOVA) followed by a multiple comparison of individual post-treatment time points to treatment time 0 (control). Supplement 1 contains the ANOVA table for each figure giving the number of replicates for each time point and the results of the multiple comparison of each post-treatment time point to treatment time 0
ph-eIF $2 \alpha$, was significantly increased by $53 \% 2 \mathrm{~h}$ after treatment (Fig. 7a, Table 1) [36]. Herp is a protein involved in ER-associated degradation (ERAD) that recruits the $26 \mathrm{~S}$ proteasome component to the ER membrane during ER stress [36]. Herp mRNA was increased by $54 \%$ $4 \mathrm{~h}$ after treatment (Fig. 7b, Table 1). In contrast, $10 \mu \mathrm{M}$ BA caused GADD153/CHOP mRNA expression to decrease. The maximum decrease in mRNA was $-59 \%$ at $12 \mathrm{~h}$ (Fig. 7c, Table 1).

\section{BA Decreases CHOP Protein}

We performed immunoblots to measure CHOP/GADD153 protein in DU- 145 cells treated with $10 \mu \mathrm{M}$ BA. CHOP protein expression was significantly decreased at $0.25,2,3,4,5$, and $6 \mathrm{~h}$ after treatment (Fig. 8a). The maximum decrease in protein was $-51 \%$ at $3 \mathrm{~h}$ after BA treatment (Table 1). The increase in CHOP protein expression following thapsigargin treatment showed that DU-145 cells responded normally to a
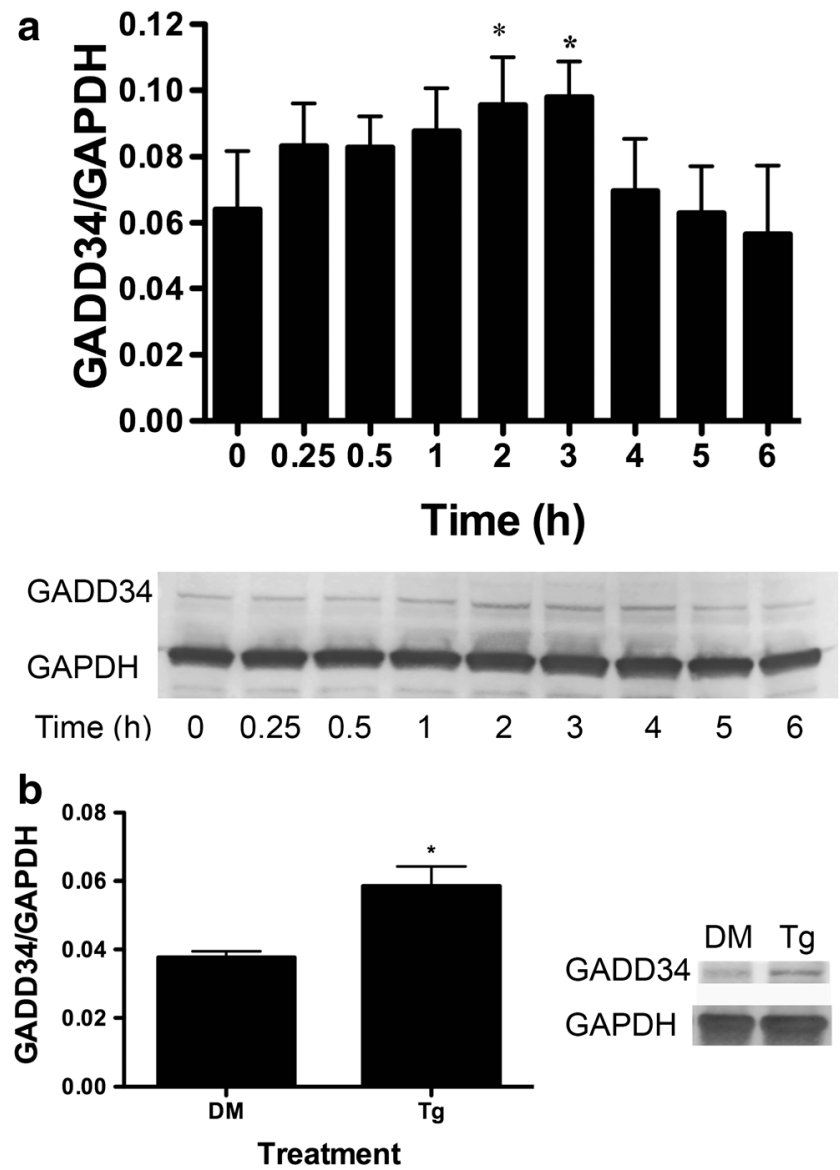

Fig. 3 BA induces an increase in GADD34 protein in DU-145 cells. a DU-145 cells were treated with $10 \mu \mathrm{M}$ BA for $0,0.25,0.5,1,2,3,4,5$, and $6 \mathrm{~h}$. GADD34 was increased in cells at $2(p=0.018, n=3)$ and $3 \mathrm{~h}$ $(p=0.011, n=3)$. b DU-145 cells treated with $1 \mu \mathrm{M}$ thapsigargin $(\mathrm{Tg})$ or DMSO (DM) for $1 \mathrm{~h},(p<0.05, n=3)$. The gel shown is a representative replicate. A description of the statistical analysis is given in the legend of Fig. 2 
known stimulus of apoptosis (Fig. 8b). The BA-induced decrease in CHOP protein expression was consistent with our observation that the same BA dose decreased CHOP mRNA (Fig. 7c) and with previous findings that DU-145 cells do not undergo apoptosis with BA treatment even at a concentration of $1000 \mu \mathrm{M}$, a dose known to cause reproductive and developmental toxicity [14].

\section{BA Induces ATF6 Activation}

In response to ER stress, the ER resident protein, ATF6, is translocated to the Golgi apparatus where it undergoes proteolysis by the S1P/S2P protease system. The resulting soluble cytoplasmic fragments enter the nucleus and activate transcription of target genes with ER stress response elements (ERSEs), such as GRP78/BiP [37]. We measured the proportion of cleaved ATF6 protein (p70) relative to the full length (p100) and observed an increase 30 min post-treatment (Fig. 9b). ATF6 measured using immunofluorescence was present in the nucleus 1 and $2 \mathrm{~h}$ after treatment with $10 \mu \mathrm{M}$ BA (Fig. 9a). The maximum increase in ATF6 activation was $77 \%$ at $30 \mathrm{~min}$, and the increase in the p70/p100 ratio was $29 \%$ at $2 \mathrm{~h}$ (Fig. 9a, b, Table 1).

\section{BA Increases Transcription of ATF6 Target Genes}

Cleaved ATF6 is a transcription factor for genes that contain ERSEI in their promoter [36]. ATF6-inducible genes include the two $\mathrm{Ca}^{2+}$-binding proteins GRP78/BiP and calreticulin as well as GRP94 and XBP1 [38]. We measured the mRNA levels of these genes by RT-PCR following treatment of DU-145 cells. Ten-micromole BA treatment increased
Table 1 Time of maximum response of untreated cells (0 min) to treatment with $10 \mu \mathrm{m}$ boric acid

\begin{tabular}{|c|c|}
\hline Gene (symbol(s)) & $\begin{array}{l}\text { Measured response; maximum } \\
\text { change; post-treatment time } \mathrm{e}^{\mathrm{a}}\end{array}$ \\
\hline $\begin{array}{l}\text { Eukaryotic translation initiation factor (EIF2A) } \\
\text { Activating transcription factor } 4(\mathrm{ATF} 4)^{\mathrm{b}}\end{array}$ & $\begin{array}{l}\text { Phosphorylation; +125\%; } 60 \mathrm{~min} \\
\text { mRNA; +46\%; } 2 \mathrm{~h} \\
\text { Protein; +53\%; } 3 \mathrm{~h}\end{array}$ \\
\hline \multicolumn{2}{|l|}{ ATF4-activated genes } \\
\hline $\begin{array}{l}\text { Growth arrest and DNA damage-inducible protein } 34 \\
\text { (GADD34); Protein phosphatase } 1 \text { regulatory subunit 15A } \\
\text { (PPP1R15A) }\end{array}$ & $\begin{array}{l}\text { mRNA; }+125 \% ; 2 \mathrm{~h} \\
\text { Protein; }+53 \% ; 2 \mathrm{~h}\end{array}$ \\
\hline $\begin{array}{l}\text { DNA damage inducible transcript } 3 \text { (CHOP; } \\
\text { GADD153; DDIT3) }\end{array}$ & $\begin{array}{l}\text { mRNA; }-59 \% ; 12 \mathrm{~h} \\
\text { Protein; }-51 \% ; 3 \mathrm{~h}\end{array}$ \\
\hline $\begin{array}{l}\text { Homocysteine-inducible, endoplasmic reticulum } \\
\text { stress-inducible, ubiquitin-like domain member } 1 \\
\text { (HERP, HERPUD1) }\end{array}$ & mRNA; +56\%; 4 h \\
\hline Activating transcription factor $6 \mathrm{~A}(\mathrm{ATF} 6 \mathrm{~A})^{\mathrm{c}}$ & $\begin{array}{l}\text { Cleavage p70/p100; }+77 \% ; 30 \mathrm{~min} \\
\text { Nuclear/cytoplasm staining; }+29 \% ; 2 \mathrm{~h}\end{array}$ \\
\hline \multicolumn{2}{|l|}{ ATF6A-activated genes } \\
\hline Heat shock protein family A (Hsp70) & mRNA; +149\%; 30 min \\
\hline member 5 (GRP78; BiP; HSPA5) & Protein; +98\%; 60 min \\
\hline $\begin{array}{l}\text { ER degradation enhancer, mannosidase } \\
\text { alpha-like } 1 \text { (EDEM1) }\end{array}$ & mRNA; +110\%; $24 \mathrm{~h}$ \\
\hline $\begin{array}{l}\text { Heat shock protein } 90-\mathrm{kDa} \text { beta family } \\
\text { member } 1 \text { (GRP94; HSP90B1) }\end{array}$ & mRNA no change \\
\hline Calreticulin (CALR) & mRNA; $+52 \% ; 8 \mathrm{~h}$ \\
\hline $\mathrm{X}$-box binding protein $1(\mathrm{XBP} 1)$ & mRNA; +147\%; $24 \mathrm{~h}$ \\
\hline Endoplasmic reticulum to nucleus signaling 1 (IRE1; ERN1) ${ }^{\mathrm{c}}$ & No change or negative change \\
\hline \multicolumn{2}{|l|}{ IRE1-activated genes } \\
\hline $\mathrm{X}$-box binding protein 1 spliced $\left(\mathrm{XBP} 1^{\mathrm{s}}\right)$ & $\begin{array}{l}\text { Spliced XBP1 (XBP1s) was not } \\
\text { observed at 0-250 } \mu \mathrm{M} \text { BA }\end{array}$ \\
\hline Synoviolin 1 (HRD1; SYVN1) & mRNA; $-34 \% ; 24 \mathrm{~h}$ \\
\hline
\end{tabular}

${ }^{a}$ Maximum change from treatment with $10 \mu \mathrm{M}$ boric acid was calculated using the mean of untreated cells $(0 \mathrm{~min})$ and the highest mean value post-treatment (data available in Supplement 1). Percent $(\%)$ change $=[$ highest post-treatment value - pre-treatment value $($ at $0 \mathrm{~min})] \div$ [pretreatment value $($ at $0 \mathrm{~min})]$. Note that the first significant change may have occurred earlier; see figures

${ }^{\mathrm{b}}$ ATF 4 is activated by low levels of EIF $2 \alpha$ subsequent to EIF $2 \alpha$ phosphorylation

${ }^{\mathrm{c}}$ Stress sensor in the unfolded protein response stress pathway (UPR) 
GRP78/BiP mRNA 30 min after treatment (Fig. 10a) with a maximum of $149 \%$ (Table 1). The maximum increase in $\mathrm{BiP} /$ GRP78 protein was $98 \%$ at $1 \mathrm{~h}$ (Fig. 4, Table 1). GRP94 was unchanged (Fig. 10b). Calreticulin mRNA increased by $49 \%$ at $4 \mathrm{~h}$ (Fig. 10c) with a maximum of $52 \%$ at $8 \mathrm{~h}$ after BA treatment (Fig. 10c, Table 1). XBP1 mRNA was increased $24 \mathrm{~h}$ post-treatment by $147 \%$ (Fig. 10d, Table 1).

\section{BA Does Not Activate the IRE1 Branch of UPR}

An excessive accumulation of unfolded and misfolded proteins in the ER causes IRE-1 to dimerize allowing trans-autophosphorylation of juxtaposed kinase domains and activation of their endoribonuclease domains located in the cytoplasm [39]. Activated IRE1 splices XBP1 mRNA forming pXBP1s (spliced XBP1 protein) that binds to the unfolded protein response element (UPRE) [40]. To assess activation of the IRE1 branch of the UPR, we evaluated splicing of XBP1 mRNA using a primer specific for both spliced and unspliced forms of

a
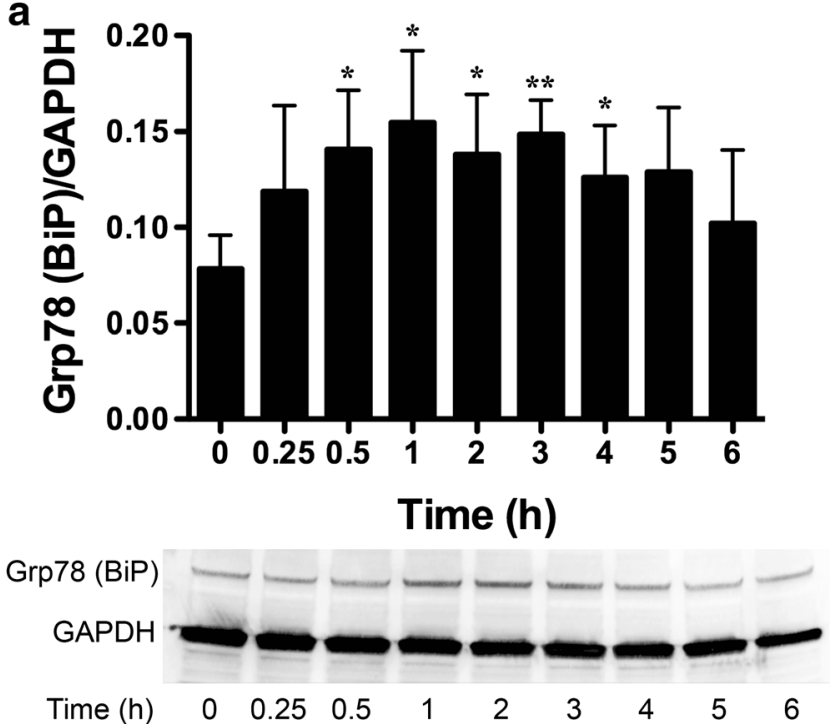

b

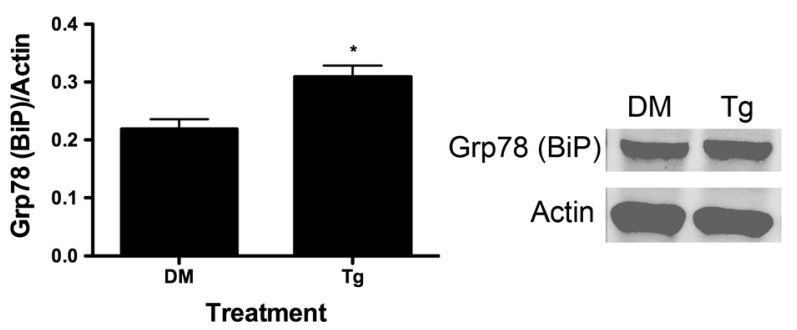

Fig. 4 BA induces an increase in GRP78 (BiP) protein in DU-145 cells. a DU-145 cells were treated with $10 \mu \mathrm{M}$ BA for $0,0.25,0.5,1,2,3,4,5$, and $6 \mathrm{~h}$. GAPDH was used as an internal loading control. GRP78/BiP translation was increased $0.5(p=0.028, n=4), 1(p=0.007, n=4), 2 \mathrm{~h}$ $(p=0.032, n=4)$, and $3 \mathrm{~h}(p=0.013, n=4)$. b DU-145 cells treated with $1 \mu \mathrm{M}$ thapsigargin (Tg) or DMSO (DM) vehicle for $1 \mathrm{~h}(p<0.05, n=3)$. The gel shown is a representative replicate. A description of the statistical analysis is given in the legend of Fig. 2

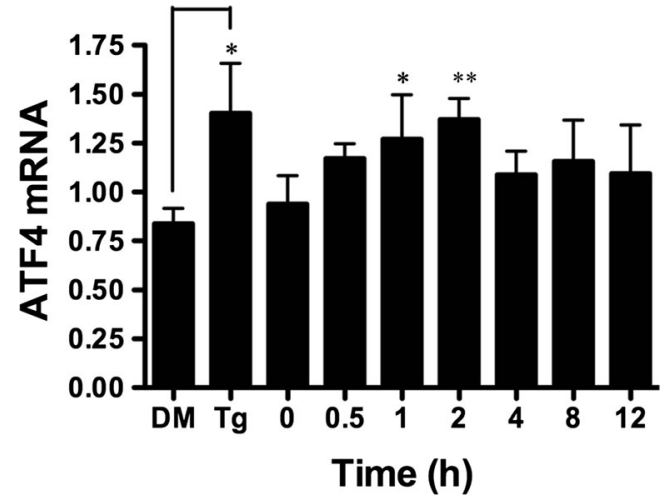

Fig. 5 BA induces an increase in ATF4 transcription in DU-145 cells. Ten micromoles of BA induced a significant increase in ATF4 mRNA 1 $(p=0.031, n=4)$ and $2 \mathrm{~h}(p=0.005, n=4)$ post-treatment. One micromole of thapsigargin (Tg) and DMSO vehicle (DM) was used as a positive control and significantly induced ATF4 mRNA, $p<0.05$ $(n=5)$. The gel shown is a representative replicate. A description of the statistical analysis is given in the legend of Fig. 2
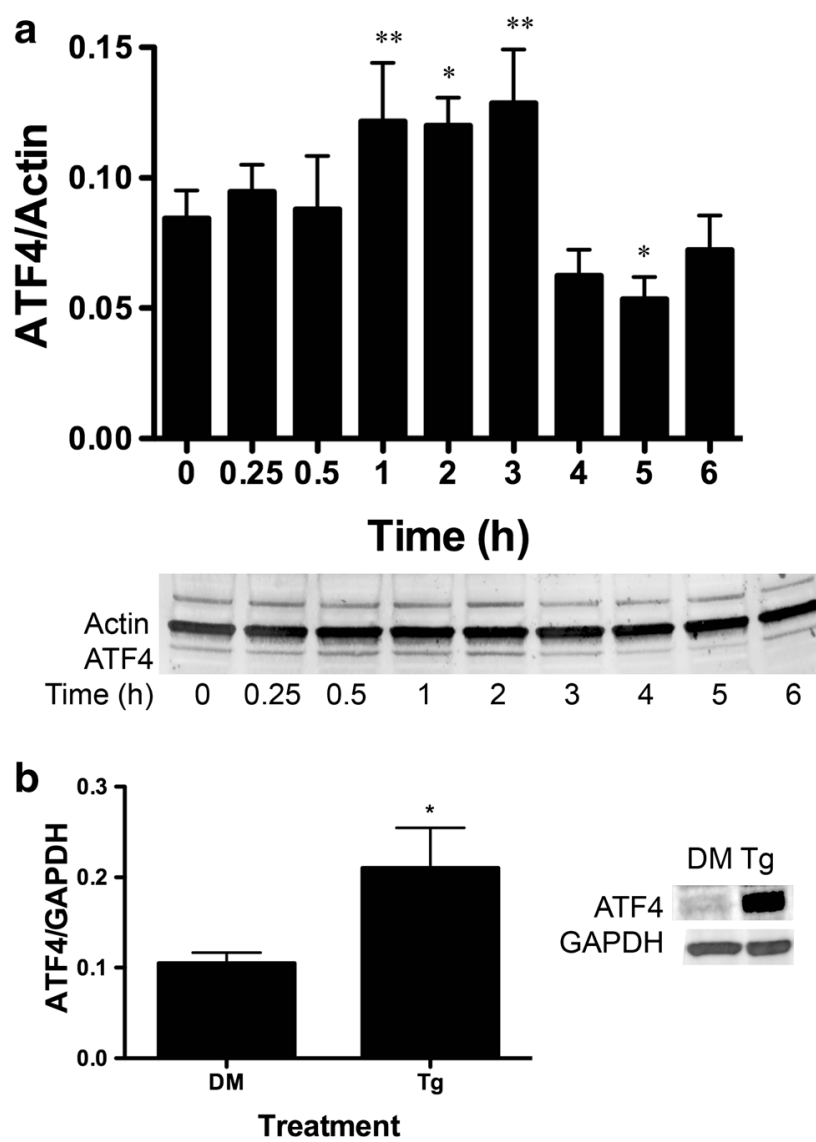

Fig. 6 BA induces an increase in ATF4 protein in DU-145 cells. a DU145 cells were treated with $10 \mu \mathrm{M}$ BA for $0,0.25,0.5,1,2,3,4,5$, and $6 \mathrm{~h}$. ATF 4 protein was significantly increased in cells treated at 1 $(p=0.01, n=4), 2(p<0.05, n=3)$, and $3 \mathrm{~h}(p=0.004, n=3)$ and decreased at $5 \mathrm{~h}(p<0.030, n=4)$ post-treatment. b ATF3 protein was significantly increased in DU-145 cells treated with $1 \mu \mathrm{M}$ thapsigargin (Tg) or DMSO (DM) for $1 \mathrm{~h},(p<0.05 n=3)$. The gel shown is a representative replicate. A description of the statistical analysis is given in the legend of Fig. 2 

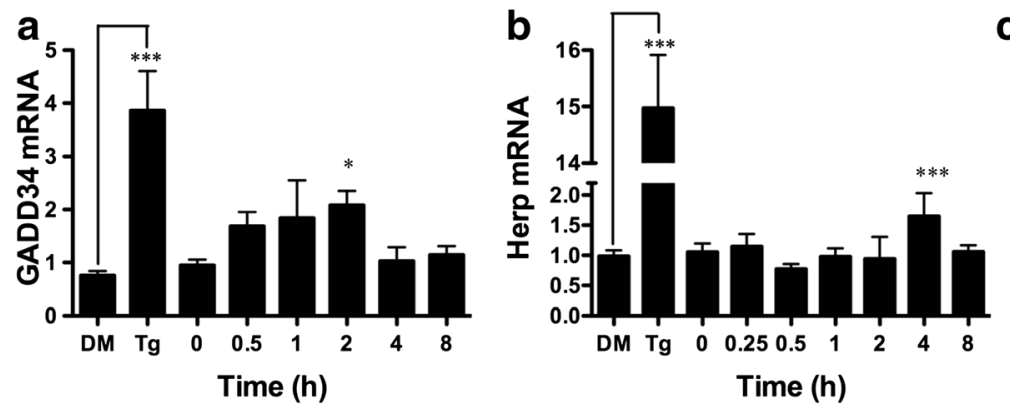

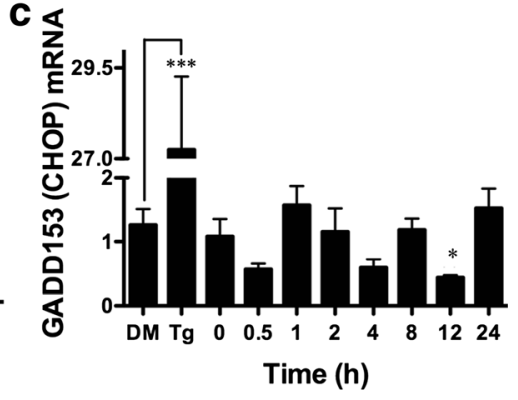

Fig. 7 ATF4-inducible genes GADD34 and Herp are upregulated and CHOP downregulated by BA in DU-145 cells. Ten micromoles of BA induced expression of a GADD34 at $2 \mathrm{~h}(p<0.05), n=4)$ and b Herp $(p<0.001, n=8))$ at $4 \mathrm{~h}$ post-treatment and $\mathbf{c}$ downregulated expression

XBP1 mRNA. When PCR products are run slowly on an agarose gel, the two forms separate into two bands of different mass if IRE-1 is activated and XBP1 mRNA is spliced. We treated DU-145 cells with BA concentrations from 10 to $250 \mu \mathrm{M}$ for $24 \mathrm{~h}$, and no splicing was observed (Fig. 11a). We also treated DU-145 cells with $10 \mu \mathrm{M}$ BA for varying time points and again did not observe spliced mRNA (Fig. 11b). These results show that BA does not induce the IRE1 branch

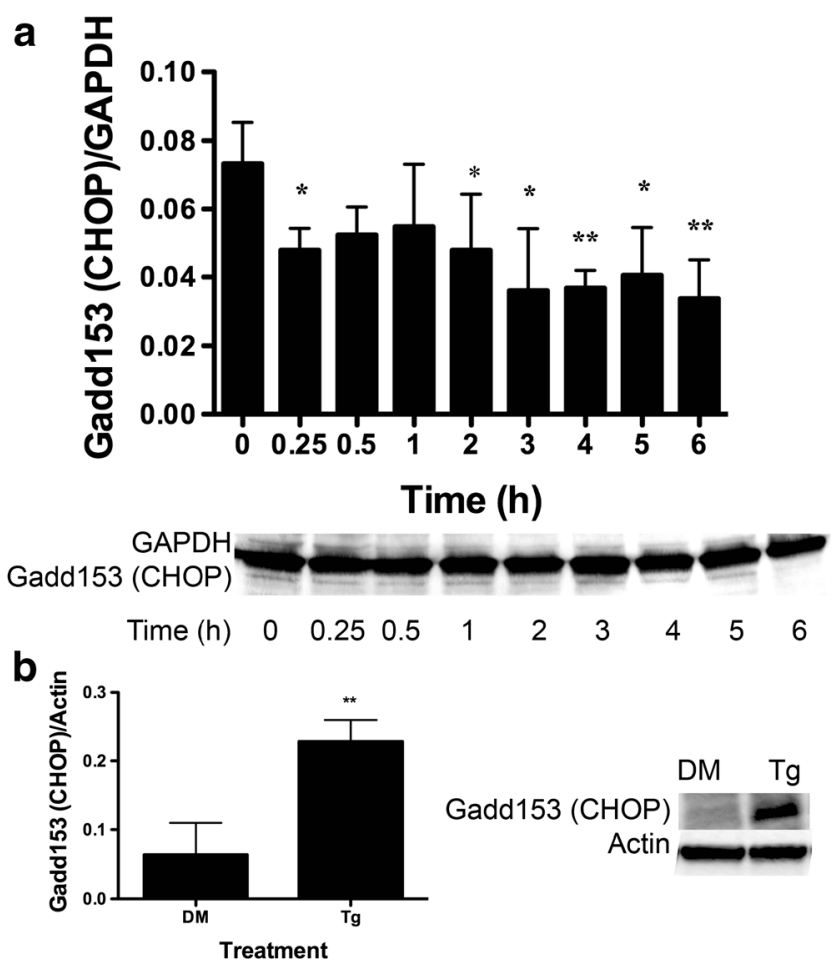

Fig. 8 GADD153 (CHOP) protein was reduced in BA-treated DU-145 cells. a DU-145 cells treated with $10 \mu \mathrm{M}$ BA for $0,0.25,0.5,1,2,3,4,5$, and $6 \mathrm{~h}$. GADD153 (CHOP) protein was decreased at $0.25(p<0.043$, $n=3), 2(p<0.033, n=3), 3(p<0.015, n=4), 4(p<0.006, n=4), 5$ $(p<0.014, n=4)$, and $6 \mathrm{~h}(p<0.003, n=4)$. b DU-145 cells treated with $1 \mu \mathrm{M}$ thapsigargin $(\mathrm{Tg})$ or DMSO (DM) vehicle for $1 \mathrm{~h}$. Thapsigargin increased GADD153 (CHOP) protein, $(p<0.05, n=3)$. The gel shown is a representative replicate. A description of the statistical analysis is given in the legend of Fig. 2 of GADD153 (CHOP) $12 \mathrm{~h}$ post-treatment $(p=0.012, n=4)$. As a positive control, $1 \mu \mathrm{M}$ thapsigargin $(\mathrm{Tg})$ upregulated expression of all three genes compared to DMSO vehicle (DM), $(p<0.05, n=3)$. A description of the statistical analysis is given in the legend of Fig. 2

of the UPR. Splicing was observed when cells were treated with thapsigargin, a known activator of IRE1 (Fig. 11a, b).

\section{BA Does Not Activate Hrd1, a Spliced XBP1-Specific Target Gene}

Spliced XBP1 that results from activation of the IRE1 branch acts as a transcription factor for a number of UPR-related genes. If BA activated IRE1, we would expect an increase in the transcription of these genes. To confirm that BA did not activate the IRE1 branch of the UPR, we used RT-PCR to analyze the expression of Hrd1 and ER degradation enhancer mannosidase alpha-like 1 (EDEM1). BA did not increase the transcription of Hrd1 which is specifically activated by spliced XBP1, but not ATF6 (Fig. 12a). EDEM1 is activated by both ATF6 and XBP1 [40]. EDEM1 mRNA was increased at $24 \mathrm{~h}$ by treatment with $10 \mu \mathrm{M}$ BA (Fig. 12b) probably due to activation by ATF6.

\section{Genes Were Active in the DU-145 Cell Line}

The positive control, thapsigargin, demonstrated that all genes evaluated were active in the DU-145 cell line. The Catalogue of Somatic Mutations in Cancer (COSMIC) recorded a mutation in ATF4 in $16.67 \%$ of prostate tumor tissue samples [28]. In the DU-145 cell line, substitution mutations were reported in ATF4 and IRE1 with no phenotypic changes. The mutations did not occur in the regulatory build, and no association was found for any gene measured and copy number or expression in the COSMIC Cell Line. Information available in COSMIC (releases v75 and v76) and Ensemble for each of the genes measured in this manuscript are available in Supplement $2[28,41]$. ATCC states that DU-145 "is a hypotriploid human cell line. Both 61 and 62 chromosome numbers had the highest rate of occurrence in 30 metaphase counts. The rate of higher ploides was $3 \%$. The $\mathrm{t}(11 \mathrm{q} 12 \mathrm{q})$, $\operatorname{del}(11) q 23), 16 q+, \operatorname{del}(9)(p 11), \operatorname{del}(1)(p 32)$ and 6 other marker chromosomes were found in most cells. The N13 was usually absent. The $\mathrm{Y}$ chromosome is abnormal through translocation 
Fig. 9 BA stimulates ATF6 activation and translocation to the nucleus. a ATF6 (green) was present in the nucleus (blue) of DU- 145 cells $1(p=0.026$, $n=17)$ and $2 \mathrm{~h}(p=0.002, n=48)$ post-treatment with $10 \mu \mathrm{M}$ BA. $\mathbf{b}$ ATF6 is activated by cleavage. The proportion of the cleaved product (p70) to full length (p100) was significantly elevated $30 \mathrm{~min}$ post-treatment $(p=0.032, n=3)$. One micromole of thapsigargin

$(\mathrm{Tg})$ also significantly increased the $\mathrm{p} 70 / \mathrm{p} 100$ ratio $(p<0.05)$ $(n=15)$. The gel shown is a representative replicate. A description of the statistical analysis is given in the legend of Fig. 2. (Color figure online) a

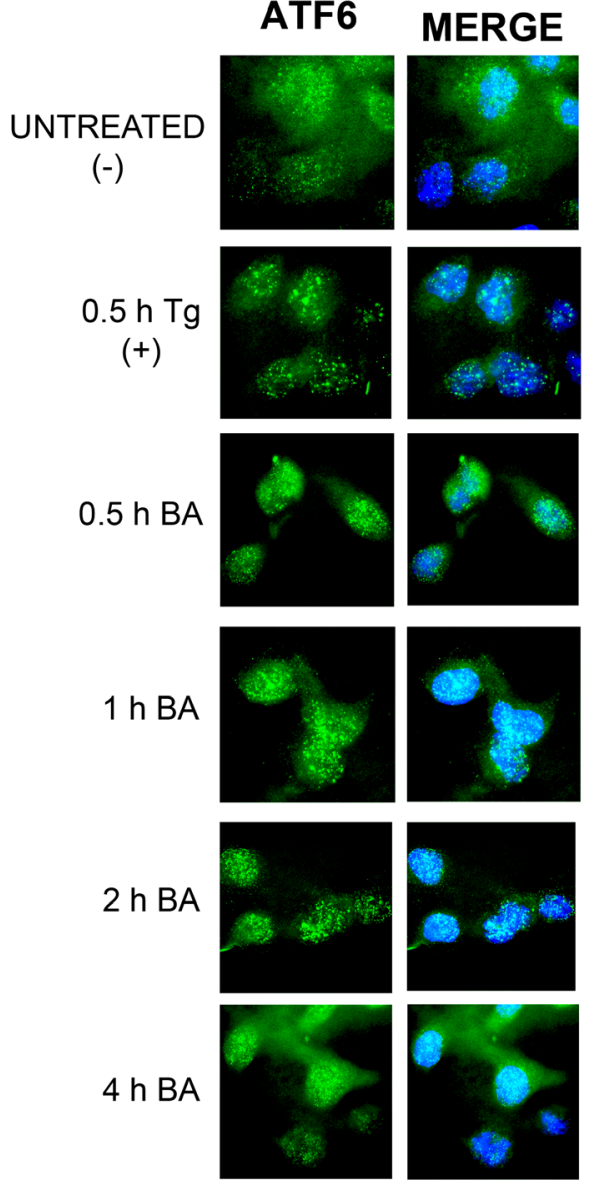

b

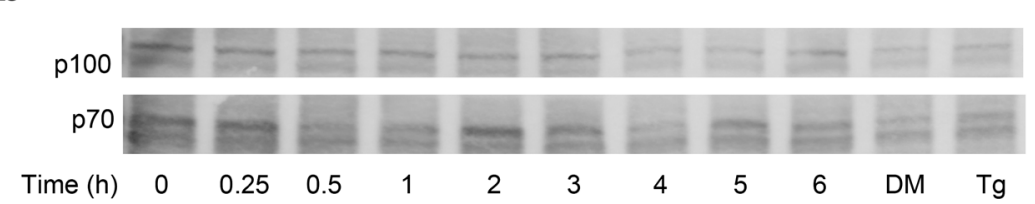

to an unidentified chromosomal segment. The $\mathrm{X}$ chromosome was present in single copy."

\section{Discussion}

We describe in this paper the response of DU-145 human prostate cells to concentrations of BA that occur from dietary exposure. We draw seven main conclusions from our results. First, BA reduces the polysome/monosome ratio, an indicator of global protein translation. Changes to the extracellular environment can alter intracellular conditions that stress the ER and inhibit global protein synthesis. Documented stresses include low ER luminal $\left[\mathrm{Ca}^{2+}\right]$; nutrient stress from glucose deprivation and amino acid deficiency; and toxic exposures from chemical, physical, and biological hazards $\left(\mathrm{NaN}_{3}\right.$, arsenite, oxidants, heat, UV radiation, and viruses) [42-44]. BA treatment lowers luminal ER $\left[\mathrm{Ca}^{2+}\right]$ as does thapsigargin, a plant sesquiterpene lactone, used widely as a strong positive control to assure that cells under study respond to a known ER stressor [15]. ER stress elicits inhibition in global translation by phosphorylation of eIF- $2 \alpha$ which is a component of the heterotrimeric eIF-2 complex that loads the initiator transfer RNA (tRNA) (Met-tRNAMet) onto the 40S ribosomal subunit [45-48]. The eIF-2 complex binds GTP/GDP, and its activity is regulated by guanine nucleotide exchange factor 

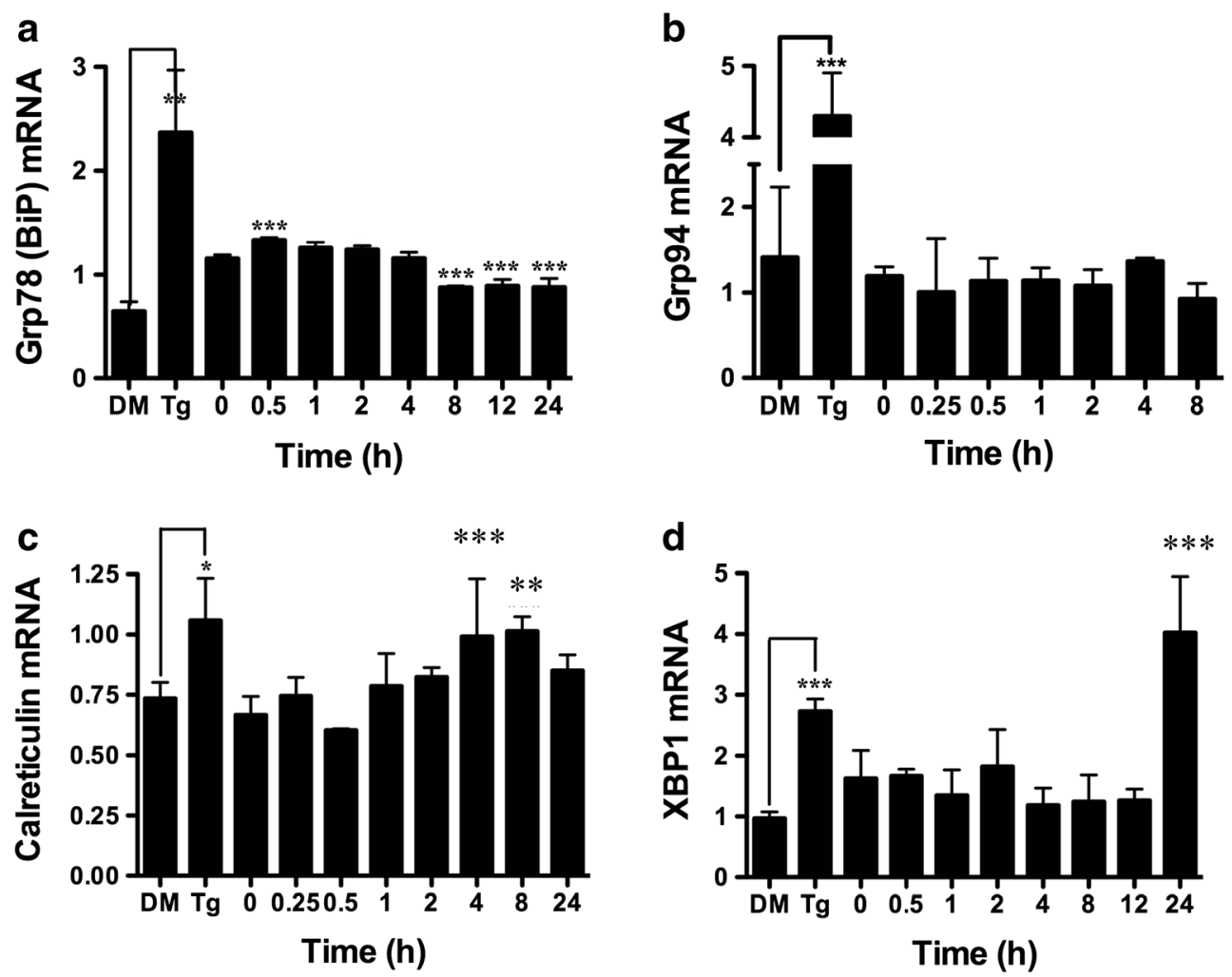

Fig. 10 BA upregulates ATF6-inducible genes BiP, GRP94, calreticulin, and XBP1. Ten micromoles of BA induced expression of a GRP78 (BiP) at $0.5 \mathrm{~h}(p<0.001, n=4)$. GRP78 returned to control levels for several hours and then dropped to lower levels at $8 \mathrm{~h}(p<0.001, n=4), 12 \mathrm{~h}$ $(p<0.001, n=4)$, and $24 \mathrm{~h}(p<0.001, n=4)$, suggesting that the cells adapted to higher concentrations of BA. b GRP94 was unchanged by

eIF-2B. Phosphorylation of eIF-2 $\alpha$ increases the affinity of eIF-2 for eIF-2B, preventing the exchange of GDP for GTP. This prevents the formation of the puromycin-sensitive $80 \mathrm{~S}$ pre-initiation complex and allows elongating ribosomes to release mRNAs, leading to the disassembly of polysomes into monosomes [48]. Here, we show that BA $(10 \mu \mathrm{M})$ treatment reduced the polysome/monosome ratio by approximately half, an indication that global protein synthesis was inhibited, but not stopped (Fig. 1). Uluisik, Kaya, and colleagues reported that $50 \mathrm{mM}$ BA completely halted polysome formation and protein synthesis in yeast [21].

Second, BA increases the transcription and translation of $\mathrm{BiP} / \mathrm{GRP} 78$, a resident ER chaperone, with a long half-

treatment. c Calreticulin was higher at $4 \mathrm{~h}(p<0.001, n=5)$ and $8 \mathrm{~h}$ $(p=0.003, n=4)$. d XBP1 was higher at $24 \mathrm{~h}$ of treatment $(p<0.001$, $n=4)$. As a positive control, $1 \mu \mathrm{M}$ thapsigargin $(\mathrm{Tg})$ upregulated expression of all genes compared to DMSO vehicle (DM) $(p<0.05$, $n=4)$. The gel shown is a representative replicate. A description of the statistical analysis is given in the legend of Fig. 2

life ( $>48 \mathrm{~h}$ ) and an indicator of ER stress (Figs. 4 and 10$)$ $[36,49]$. BiP/GRP78 binds about $20 \%$ of the ER's Ca ${ }^{2+}$ and is the master regulator of the UPR $[34,50]$. In eukaryotic cells, newly synthesized secretory and transmembrane unfolded polypeptides are transported through translocons into the ER lumen. BiP/GRP78 gates the ER side of the tranlocon $[34,51,52]$, recognizes hydrophobic regions of nascent unfolded proteins entering the ER, and assists in their folding and assembly into polypeptides [53, 54]. High $\left[\mathrm{Ca}^{2+}\right]_{\mathrm{ER}}$ is required for protein folding, and when it is low, unfolded proteins accumulate. BiP/GRP78 activates UPR pathways via its release from resident ER transmembrane proteins to remove the stress [50].

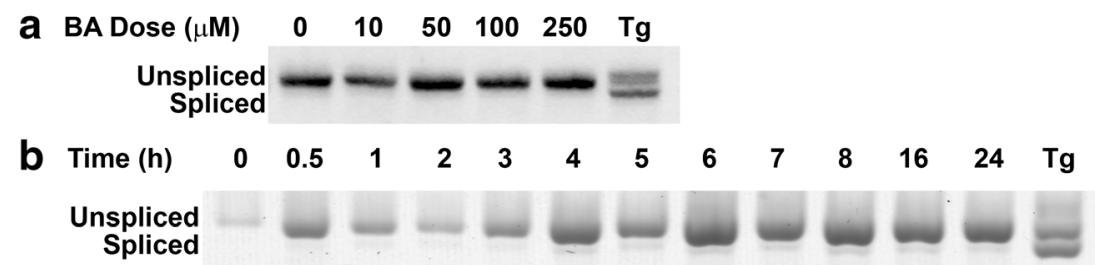

Fig. 11 BA does not activate the IRE1 signaling pathway. a DU-145 cells were treated with $0,10,50,100$, or $250 \mu \mathrm{M}$ BA or $1 \mu \mathrm{M}$ thapsigargin (Tg) for $24 \mathrm{~h}$. Thapsigargin was used as a positive control. Increasing BA concentrations for $24 \mathrm{~h}$ did not cause XBP1 cleavage. b
DU-145 cells were treated with $10 \mu \mathrm{M}$ BA for varying time points or $1 \mu \mathrm{M}$ thapsigargin $(\mathrm{Tg})$ as a positive control. XBP1 was not cleaved at any time point by BA, but it was by $\operatorname{Tg}(p<0.05, n=3)$. The gel shown is a representative replicate 


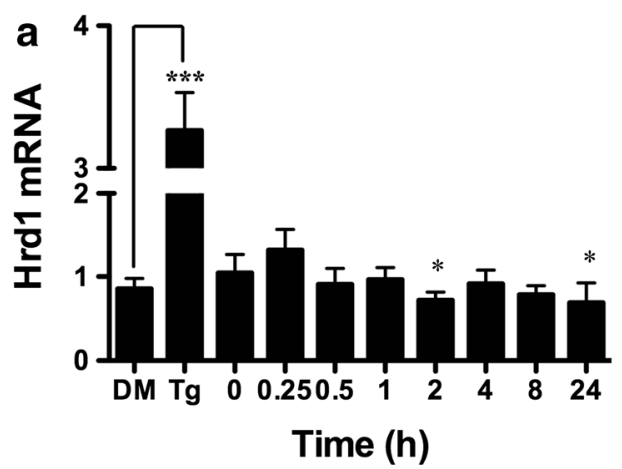

Fig. 12 BA does not activate the XBP1s-inducible gene Hrd1, but did activate Edem 1 which is also induced by ATF6 and XBP1. a Ten micromoles of BA did not induce expression of Hrd1 mRNA in DU145 cell which dropped below pre-treatment values at $2 \mathrm{~h}(p<0.05$, $n=4)$ and $24 \mathrm{~h}(p<0.05, n=3)$. b Ten micromoles of BA induced

Third, BA activation of eIF $2 \alpha$ through phosphorylation at serine 51 is transient. The interaction between BiP/GRP78 and nascent unfolded proteins is stabilized by luminal ER $\mathrm{Ca}^{2+}$, and when $\mathrm{Ca}^{2+}$ concentrations fall, BiP/GRP78 is released and interacts with PERK, a kinase that phosphorylates eIF2 $\alpha$ [50]. Treatment of cells with $10 \mu \mathrm{M}$ BA significantly elevated the ratio of phosphorylated eIF $2 \alpha /$ total eIF $2 \alpha$ at $30 \mathrm{~min}$, and it remained high up to $2 \mathrm{~h}$ (Fig. 2, Table 1). The decline in pheif $2 \alpha$ coincided with the rise in GADD34 mRNA, the phosphatase that removes the phosphate from ph-eIF2 $\alpha$ (Fig. 7a). Our observation of a return to normal suggests that the cell has completed a change in transcription to the new $10-\mu \mathrm{M}$ BA environment by $3 \mathrm{~h}$ and that a comparison of polysomes before BA treatment and at $3 \mathrm{~h}$ would provide a means to identify BA-dependent changes in protein translation.

Fourth, BA upregulates the transcription factor, ATF4. Phosphorylation of eIF $2 \alpha$ increases upstream open reading frame (uORF)-mediated translation of bone-related activating transcription factor 4 (ATF4). The ph-eIF2 $\alpha /$ ATF4 pathway is highly conserved from yeast to mammals and has been named the ISR because it is a target of many different types of environmental stresses [55]. Treatment with BA resulted in an increase in ATF4 mRNA and protein levels (Figs. 5 and 6, Table 1). ATF4-inducible gene GADD34 increased immediately whereas the increase in Herp, which is dually regulated by ATF6 and ATF4 [56], was delayed to $4 \mathrm{~h}$ (Fig. 7b). In neurons, moderate levels of ER stress increase Herp levels, which promotes cell survival by stabilizing ER $\mathrm{Ca}^{2+}$, preserving mitochondrial function and suppressing caspase 3 , whereas lethal stress levels decrease Herp levels and induce apoptosis [57]. In neuronal PC12 cells, promotion of cell survival is accomplished by Herp's association with ryanodine and inositol $\mathrm{Ca}^{2+}$ channels and facilitation of their proteasomemediated protein degradation [58].

Fifth, BA reduced the CHOP, also referred to as growth arrest-inducible and DNA damage-inducible gene 153 (GADD153), at both the mRNA and protein levels (Figs. 7c

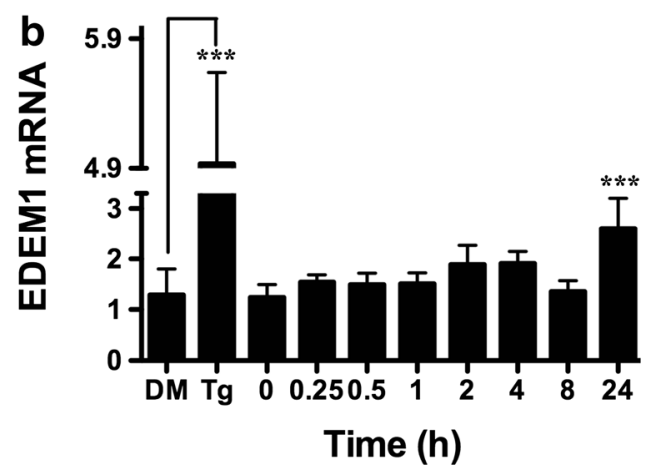

expression of Edem 1 at $24 \mathrm{~h}(p<0.001, n=4)$ which is regulated by ATF6 and IRE1. As a positive control $1 \mu \mathrm{M}$ thapsigargin ( $\mathrm{Tg}$ ) upregulated expression of both genes compared to DMSO vehicle (DM), $(n=6)$. The gel shown is a representative replicate. A description of the statistical analysis is given in the legend of Fig. 2

and 8). This outcome is consistent with previous reports showing that BA does not cause apoptosis in DU-145 prostate cells or MDA-MB-231 breast cancer cells at concentrations of $1 \mathrm{mM}$ or less $[5,59]$. The absence of CHOP activation by $\mathrm{BA}$ is also consistent with the anti-apoptotic activity of $\mathrm{BiP} /$ GRP78 and Herp and the absence of BA activation of IRE1 (Figs. 11 and 12a). This can be explained by the low level of eIF $2 \alpha$ phosphorylation induced by BA. A single uORF located in the $5^{\prime}$-leader of the CHOP mRNA is responsible for CHOP translation. In non-stress conditions and when eIF $2 \alpha$ phosphorylation is low, the uORF serves as a barrier that prevents translation of the downstream CHOP coding region. Lethal stress levels, such as those induced by thapsigargin, induce a high level of eIF $2 \alpha$ phosphorylation which facilitates ribosome bypass of the $\mathrm{UORF}$ and allows translation [60].

Sixth, BA activates the ATF6 pathway. BA causes a dose- and time-dependent expansion of the ER with the formation of cytoplasmic stress granules (SGs) [19]. ER expansion is induced by ATF6 $\alpha$ [61] and independently by $\mathrm{pXBP} 1 \mathrm{~s}$ via the IRE1 pathway $[62,63]$. We show here that treatment with BA activated ATF6 $\alpha$, but not IRE1 (Figs. 9, 10, 11, and 12). ATF6 is retained in the ER bound to BiP/GRP78 and dissociates when unfolded proteins accumulate. ATF6 moves to the Golgi where it is cleaved by S1P and S2P proteases to form a soluble basic leucine zipper (bZIP) transcription factor that moves into the nucleus [34]. Nuclear ATF6 binds to an ERSE promoter located upstream of target genes which include BiP/GRP78, calreticulin, and XBP1 [40]. Calreticulin mRNA increased by $49 \%$ at $4 \mathrm{~h}$ (Fig. 10c). Calreticulin is a major ER $\mathrm{Ca}^{2+}$ binding protein and increases luminal $\mathrm{Ca}^{2+}$ stores $[64,65]$. As a chaperone, it recognizes the terminal glucose and four internal mannoses in newly synthesized glycoproteins [66]. Reductions in ER $\mathrm{Ca}^{2+}$ decrease the formation of these complexes and ER folding capacity. Calreticulin facilitates the folding of major histocompatibility complex (MHC) class I molecules and their assembly factor tapasin, 
thereby influencing antigen presentation to cytotoxic $\mathrm{T}$ cells $[67,68]$. It is also required for the stability and nuclear localization of the $\mathrm{p} 53$ protein [69]. Further studies are needed to determine if the ability of BA to induce calreticulin transcription is related to its effects on the immune system [11].

The second ATF6-regulated gene we evaluated was $\mathrm{BiP} /$ GRP78. In HeLa cells, thapsigargin induced rapid BiP translation that preceded transcription [70]. The authors suggested that storage of BiP/GRP78 mRNA transcripts allows cells to rapidly synthesize the protein to adapt to small perturbations and reserve transcriptional upregulation for conditions that cause major reductions in the protein level [70].

ATF6 induces XBP1 mRNA under mild stress whereas higher levels of stress induce XBP1 and IRE1-dependent XBP1(s) [40]. ATF6 $\alpha$ forms a heterodimer with XBP1 which induces ER degradation enhancing $\alpha$-mannosidase-like 1 (EDEM1). EDEM1 enhances the release of terminally misfolded glycoproteins from the calnexin chaperone system. In our study, XBP1 and EDEM1 mRNA were increased by 147 and $110 \%$, respectively, at the 24-h BA treatment (Fig. 12b, Table 1).

Seventh, BA does not activate IRE1. The IRE1 pathway transactivates the transcription of genes encoding ER chaperones and components required for ERAD [71]. High levels of stress induce XBP1 and XBP1(s) which is translated into the $\mathrm{XBP} 1$ transcription factor protein [pXBP1(s)] that binds to ERSE and UPRE DNA-binding sites to induce expression of ER chaperones [40]. IRE1 is required for the site-specific cleavage of XBP1 mRNA into fragments that are subsequently ligated to form the transcript encoding pXBP1(s). We did not observe XBP1 cleavage in BA-treated cells at various doses and time points (Fig. 11) nor was there an increase in transcription of Hrd1, a pXBP1(s)-activated gene (Fig. 12a).

In previous studies using DU-145 and LNCaP prostate cancer cells, we showed that long-term exposure to BA ( 8 days) induces a senescent-like state and inhibits proliferation in a dose-dependent manner [5]. Long-term exposure to high concentrations of BA (250 and $1000 \mu \mathrm{M})$ inhibited both cell migration and invasion [72]. Bradke and colleagues extended these observations to shorter periods of exposure and showed that a 24-h exposure to $1000 \mu \mathrm{M}$ BA inhibited migration of DU-145 cells on fibronectin [73]. The concentrations used in these migration studies are above what human cells would be exposed to from normal dietary intake and occupational exposure [13]. Dose response studies are needed in migration and other studies to clarify those responses that can be achieved by dietary $\mathrm{B}$ intake and those that require pharmaceuticals. The observations presented here suggest caution in interpreting genetic responses to BA since they are time dependent. Understandably, this makes the results of single time-point studies using arrays of multiple genes particularly challenging to interpret. It also seems prudent that BA-sensitive periods be identified prior to conducting dose response experiments.

\section{Conclusion}

Dietary boron has been connected to three seemingly unconnected observations, increased bone mass and strength [10, $74,75]$, chemoprevention $[1,3,4,6]$, and prevention of retinal degeneration [76]. BiP/GRP78 is expressed in the mineralizing matrices of teeth and bone and in the extracellular matrix of differentiating human marrow stromal cells and dental pulp stem cells. BiP/GRP78 binds to type I collagen and dentin matrix protein 1 and aids in the nucleation of calcium phosphate [77]. ATF4 regulates osteogenesis during development and postnatal bone remodeling and upregulates osteocalcin [78]. Parathyroid hormone, an essential regulator of endochondral bone formation and an important anabolic agent for the reversal of bone loss, mediates its functions in part by regulating the binding of ATF4 to the osteoblast-specific gene, osteocalcin [79]. BiP/GRP78 and EDEM prevent aggregation of misfolded opsin leading to retinal degeneration $[80,81]$. Our present observation that BA increased both BiP/GRP78 and EDEM provides a hypothesis for the observed retinal degeneration in B-depleted zebrafish [76].

$\mathrm{BA}$ inhibits the cADPR $\mathrm{Ca}^{2+}$ pathway which activates cell proliferation and inhibits differentiation $[15,82]$ and activates TIA-1 [18] which has been reported to inhibit tumor progression and invasion [83]. Here, we show that BA treatment increased GRP78 which inhibits cell migration [84] and calreticulin which suppresses prostate cancer by inhibiting growth and metastasis [85]. Calreticulin is also necessary for p53 function an important tumor suppressor [69].The eIF2 $\alpha$ / ATF4 and ATF6 pathways are downregulated in genetic models of prostate cancer, and their activation by BA is consistent with its reported chemopreventative effect in human populations [86].

Our studies were performed at a BA concentration that can be achieved by diet. The median consumption of boron in the USA ranges from 0.75 to $1.35 \mathrm{mg} \mathrm{B}$ /day in adults and is derived primarily from dietary plants. Borates provide the essential diester link between chains of the pectic polysaccharide rhamnogalactanuran II (RG-II) that is essential for plant growth. RGII occurs in the cell walls of gymnosperms and angiosperms and is a soluble plant fiber that constitutes 15$30 \%$ of dietary fiber [87]. Boron-rich food sources include tree nuts and peanuts, fruits, vegetables, legumes, and wine which, along with olive oil, are the signature of the Mediterranean diet. The NIH-AARP study reported that this diet decreased cancer mortality by $17 \%$ in men and $13 \%$ in women during a 5-year study period [88]. Determining how important boron was to this outcome will require teasing out the relative contributions of dietary components. In the meantime, we find it of interest that coffee in North America and soybeans in China are the major contributors of boron to the diet $[89,90]$, and both have been associated with reduced risk of prostate cancer [91, 92]. 
Acknowledgments UC Toxic Substances and Training Grant to the UCLA Molecular Toxicology Program provided partial support for SK, $\mathrm{KH}$, and KY. Other support was provided from remunerations for teaching for $\mathrm{CE}$.

Authors' Contributions All authors contributed intellectually to this manuscript. SK, KH, and KY conducted the experiments, analyzed data, and prepared figures and manuscript drafts. CE performed the statistical analysis of data and prepared the final manuscript, Table 1, and Supplements 1 and 2 .

Compliance with Ethical Standards This article does not contain any studies with human or animal subjects performed by any of the authors.

Conflict of Interest The authors declare that they have no conflict of interest.

Open Access This article is distributed under the terms of the Creative Commons Attribution 4.0 International License (http:// creativecommons.org/licenses/by/4.0/), which permits unrestricted use, distribution, and reproduction in any medium, provided you give appropriate credit to the original author(s) and the source, provide a link to the Creative Commons license, and indicate if changes were made.

\section{References}

1. Barranco W, Hudak P, Eckhert C (2007a) Evaluation of ecological and in vitro effects of boron on prostate cancer risk. Cancer Causes Control 18:71-77

2. Barranco W, Hudak P, Eckhert CD (2007b) Erratum: evaluation of ecological and in vitro effects of boron on prostate cancer risk. Cancer Causes Control 18:583-584

3. Cui Y, Winton M, Zhang Z, Rainey C, Marshall J, et al. (2004) Dietary boron intake and prostate cancer risk. Oncol Rep 11:887892

4. Muezzinoglu T, Korkmaz M, Nese N, Bakirdere S, Arslan Y, et al. (2011) Prevalence of prostate cancer in high boron-exposed population: a community-based study. Biol Trace Elem Res

5. Barranco W, Eckhert C (2004) Boric acid inhibits prostate cancer cell proliferation. Cancer Lett 216:21-29

6. Mahabir S, Spitz MR, Barrera SL, Dong YQ, Eastham C, et al. (2008) Dietary boron and hormone replacement therapy as risk factors for lung cancer in women. Am J Epidemiol 167:1070-1080

7. Penland JG (1998) The importance of boron nutrition for brain and psychological function. Biol Trace Elem Res 66:299-317

8. Meacham S, Taper L, Volpe S (1994) Effects of boron supplementation on bone mineral density and dietary, blood, and urinary calcium, phosphorus, magnesium, and boron in female athletes. Environ Health Perspect 102(Suppl.7):79-82

9. Chapin RE, WW K, Kenney A, McCoy H, Gladen B, et al. (1997) The effects of dietary boron on bone strength in rats. Fundam Appl Toxicol 35:205-215

10. Nielsen FH, Stoecker BJ (2009) Boron and fish oil have different beneficial effects on strength and trabecular microarchitecture of bone. J Trace Elem Med Biol 23: 195-203.

11. Hunt CD (2003) Dietary boron: an overview of the evidence for its role in immune function. J Trace Elem Exper Med 16:291-306

12. IOM (2001) Dietary reference intakes for vitamin a, vitamin K, arsenic, boron, chromium, copper, iodine, iron, manganese, molybdenum, nickel, silicon, vanadium, and zinc. National Academy Press, Washington, D.C.
13. Culver BD, Shen PT, Taylor TH, Lee-Feldstein A, Anton-Culver H, et al. (1994) The relationship of blood- and urine-boron to boron exposure in borax-workers and the usefulness of urine-boron as an exposure marker. Environ Health Perspect 102(Suppl 7):133-137

14. Barranco W, Eckhert CD (2006) Cellular changes in boric acidtreated DU145 prostate cancer cells. Br J Cancer 94:884-890

15. Henderson K, Stella J, Kobylewski SL, Eckhert CD (2009) Receptor activated $\mathrm{Ca} 2+$ release is inhibited by boric acid in prostate cancer cells. PLoS One 4:e6009

16. Kim DH, Hee QS, Norris A, Faull KF, Eckhert CD (2006) Boric acid inhibits ADP-ribosyl cyclase non-competitively. J Chromatography A 1115:246-252

17. Blaustein MP, Golovina VA (2001) Structural complexity and functional diversity of endoplasmic reticulum $\mathrm{Ca} 2+$ stores. Trends Neurosci 24:602-608

18. Henderson K, Kobylewski S, Yamada K, Eckhert C (2015) Boric acid induces cytoplasmic stress granule formation, eIF2 alpha physphorylation, and ATF4 in prostate DU-145 cells. Biometals 28:133-141

19. Henderson KA, Eckhert CD (2006) Boric acid induces ER stress and UPR in human prostate DU-145 and LNCaP cancer cells. FASEB J 20:A560

20. Henderson KA (2009) Boric acid localization and effects on storage calcium release and the endoplasmic reticulum in prostate cancer cells. Dissertation, University of California Los Angeles

21. Uluisik I, Kaya A, Formenko DE, Karakaya HC, Carlson BA, et al. (2011) Boron stress activates the general amino acid control mechanism and inhibits protein synthesis. PLoS One 6:e27772

22. Wallace J, Hannon-Fletcher M, Robson P, Gilmore W, Hubbard S, et al. (2002) Boron supplementaton and activated factor VII in healthy men. Eur J Clin Nutr 56:1102-1107

23. Litovita T, Klein-Schwartz W, Oderda G, Schmitz B (1988) Clinical manifestation of toxicity in a series of 784 boric acid ingestions. Am J Emerg Med 6:209-213

24. ATCC. https://www.atcc.org. Accessed 22 Jan 2016

25. Bennett A, Rowe RI, Soch N, Eckhert CD (1999) Boron stimulates yeast (Saccharomyces cerevisiae) growth. J Nutr 129:2236-2238

26. Yoshida H, Matsui T, Yamamoto A, Okada T, Mori K (2001) XBP1 mRNA is induced by ATF6 and spliced by IRE1 in response to ER stress to produce a highly active transcription factor. Cell 107:881-891

27. Lytton J, Westlin M, Hanley MR (1991) Thapsigargin inhibits the sarcoplasmic or endoplasmic reticulum Ca-ATPase family of calcium pumps. J Biol Chem 266:17067-17071

28. Forbes S, Beare D, Gunasekaran P, Leung K, Bindal N, et al. (2015) COSMIC: exploring the world's knowledge of somatic mutations in human cancer. Nucl Acids Res 43 (D!): D805-D811.

29. Ron D (2002) Translational control in the endoplasmic reticulum stress response. J Clin Investig 110:1383-1388

30. Spirin AS (1996) Masked and translatable messenger ribonucleoproteins in higher eukaryotes. In: Hershey SWB, Mathews MB, Sonenberg N (eds) Translational control. Cold Spring Harbor Lab. Press, Cold Spring Harbor, NY, pp. 319-334

31. Kedersha NL, Gupta M, Li W, Miller I, Anderson P (1999) RNAbinding proteins TIA-1 and TIAR link the phosphorylation of eIF2a to the assembly of mammalian stress granules. J Cell Biol 147: 1431-1441

32. Zoll WL, Horton LE, Komar AA, Hensold JO, Merrick WC (2002) Characterization of mammalian eIF2A and identification of the yeast homolog. J Biol Chem 277:37079-37087

33. Brush MH, Weiser DC, Shenolikar S (2003) Growth/arrest and DNA damage-inducible protein GADD34 targets protein phosphatase $1 \alpha$ to the endoplasmic reticulum and promote dephosphorylation of the $\alpha$ subunit of eukaryotic translation initiation factor 2 . Mol Cell Biol 23:1292-1303 
34. Hendershot LM (2004) The ER chaperone BiP is the master regulator of ER function. Mount Sinai. J Med 71:289-297

35. Pfaffenbach KT, Lee AS (2011) The critical role of GRP78 in physiologic and pathologic stress. Curr Opin Cell Biol 23:150-156

36. Schroder M, Kaufman RJ (2005) The mammalian unfolded protein response. Annu Rev Biochem 74:739-789

37. Yamamoto K, Yoshida H, Kokame K, Kaufman RJ, Kazutoshi M (2004) Differential contributions of ATF6 and XBP1 to the activation of endoplasmic reticulum stress-responsive cis-acting elements ERSE, UPRE and ERSE-II. J Biochem 136:343-350

38. Conn PM (2011) In: Conn PM (ed) Methods in enzymology. Academic Press, London

39. Zhou J, Liu CY, Back SH, Clark RL, Peisch D, et al. (2006) The crystal structure of human IRE1 luminal domain reveals a conserved dimerization interface required for activation of the unfolded protein response. Proc Natl Acad Sci U S A 103:14343-14348

40. Yamamoto K, Sato T, Matsui T, Sato M, Okada T, et al. (2007) Transcriptional induction of mammalian ER quality control proteins is mediated by single or combined action of ATF6alpha and XBP1. Dev Cell 13:365-376

41. Ensemble. http://www.ensembl.org/index.html. Accessed 15 Jan 2016

42. Anderson P, Kedersha N (2008) Stress granules: the Tao of RNA triage. Trends Biochem Sci 33:141-150

43. Zhu Y, Fenik P, Zhan G, Sanfillipo-Cohn B, Naidoo N, et al. (2008) Eif-2a protects brainstem motoneurons in a murine model of sleep apnea. J Neurosci 28:2168-2178

44. Carew JS, Nawrocki ST, Krupnik YV, Dunner K Jr, McConkey DJ, et al. (2006) Targeting endoplasmic reticulum protein transport: a novel strategy to kill malignant B cells and overcome fludarabine resistance in CLL. Blood 107:222-231

45. Berlangad J, Herrero S, De Haro C (1998) Characterization of the hemin-sensitive eukaryotic initiation factor 2a kinase from mouse nonerythroid cells. J Biol Chem 273:32340-32346

46. Gray NK, Wickens M (1998) Control of translation initiation in animals. Annu Rev Cell Dev Biol 14:399-458

47. Srivastava SP, Kumar KU, Kaufman RJ (1998) Phosphorylation of eukaryotic translation initiation factor 2 mediates apoptosis in response to activation of the double-stranded RNA-dependent protein kinase. J Biol Chem 273:2416-2423

48. Harding HP, Zhang Y, Ron D (1999) Protein translation and folding are coupled by an endoplasmic-reticulum resident kinase. Nature 397:271-274

49. Hendershot LM, Kearney JF (1988) A role for human heavy chain binding protein in the developmental regulation of immunoglobin transport. Mol Immun 25:585-595

50. Lievremont JP, Rizzuto R, Hendershot L, Meldolesi J (1997) BiP, a major chaperone protein of the endoplasmic reticulum lumen, plays a direct and important role in the storage of the rapidly exchanging pool of Ca2+. J Biol Chem 272:30873-30879

51. Van Coppenolle F, Vanden Abeele F, Slomianny C, Flourakis M, Hesketh J, et al. (2004) Ribosome-translocon complex mediates calcium leakage from endoplasmic reticulum stores. J Cell Sci 117:4135-4142

52. Schauble N, Lang S, Jung M, Cappel S, Schorr S, et al. (2012) BiPmediated closing of the Sec61 channel limits $\mathrm{Ca} 2+$ leakage from the ER. EMBO J 31:3282-3296

53. Haas IG, Wabl M (1983) Immunoglobulin heavy chain binding protein. Nature 306:387-389

54. Bole DG, Hendershot LM, Kearney JF (1986) Posttranslational association of immunoglobulin heavy chain binding protein with nascent heavy chains in nonsecreting and secreting hybridomas. $\mathrm{J}$ Cell Biol 102:1558-1556

55. Harding H, Zhang Y, Zeng H, Novoa I, Lu P, et al. (2003) An integrated stress response regulates amino acid metabolism and resistance to oxidative stress. Mol Cell 11:619-633
56. Ma Y, Hendershot L (2004) Herp is dually regulated by both the endoplasmic reticulum stress-specific branch of the unfolded protein response and a branch that is shared with other cellular stress pathways. J Biol Chem 279:13792-13799

57. Chan SL, Fu W, Zhang P, Cheng A, Lee J, et al. (2004) Herp stabilizes neuronal $\mathrm{Ca} 2+$ homeostasis and mitochondrial function during endoplasmic reticulum stress. J Biol Chem 279:2873328743

58. Belal C, Ameli NJ, El Kommos A, Bezalel S, Al'Khafaji AM, et al. (2012) The homocysteine-inducible endoplasmic reticulum (ER) stress protein Herp counteracts mutant $\alpha$-synuclein-induced ER stress via the homeostatic regulation of ER-resident calcium release channel proteins. Hum Mol Genet 21:963-977

59. Scorei R, Ciubar R, Ciofrangeanu C, Mitran V, Cimpean A, et al. (2008) Comparative effects of boric acid and calcium fructoborate on breast cancer cells. Biol Trace Elem Res 122:197-205

60. Palam LR, Baird TD, Wek RC (2011) Phosphorylation of eIf2 facilitates ribosomal bypass of an inhibitory upstream ORF to enhance CHOP translation. J Biol Chem 286:10939-10949

61. Bommiasamy H, Back SH, Fagone P, Lee K, Meshinchi S, et al. (2009) ATF6-alpha induces XBP1-independent expansion of the endoplasmic reticulum. J Cell Sci 122:1626-1636

62. Sriburi R, Jackowski S, Mori K, Brewer JW (2004) XBP1: a link between the unfolded protein response, lipid biosynthesis, and biogenesis of the endoplasmic reticulum. J Cell Biol 167:35-41

63. Sriburi R, Bommiasamy H, Buldak GL, Robbins GR, Frank M, et al. (2007) Coordinate regulation of phospholipid biosynthesis and secretory pathway gene expression in XBP-1(S)-induced endoplasmic reticulum biogenesis. J Biol Chem 282:7024-7034

64. Michalak M, Parker MM, Opas M (2002) Ca2+ signaling and calcium binding chaperones of the endoplasmic reticulum. Cell Calcium 32:269-278

65. Nakamura K, Zuppini A, Arnaudeau S, Lynch J, Ahsan I, et al. (2001) Functional specialization of calreticulin domains. J Cell Biol 154:961-972

66. Trombetta ES (2003) The contribution of N-glycans and their processing in the endoplasmic reticulum to glycoprotein biosynthesis. Glycobiology 13: 77R-91R.

67. Raghavan M, Wijeyesakere SJ, Peters LR, Del Cid N (2013) Calreticulin in the immune system: ins and outs. Trends Immunol 34:13-21

68. Gao B, Adhikari R, Howarth M, Nakamura K, Gold MC, et al. (2002) Assembly and antigen-presenting function of MHC class I molecules in cells lacking the ER chaperone. Immunity:99-109

69. Mesaeli N, Phillipson C (2004) Impaired p53 expression, function, and nuclear localization in calreticulin-deficient cells. Mol Biol Cell 15:1862-1870

70. Gulow K, Bienert D, Hass IG (2002) BiP is feed-back regulated by control of protein translation efficiency. J Cell Sci 115:2443-2452

71. Yoshida H, Matsui T, Hosokawa N, Kaufman R, Nagata K, et al. (2003) A time-dependent phase shift in the mammalian unfolded protein response. Dev Cell 4:265-271

72. Barranco W, Eckhert C (2006) Cellular changes in boric acidtreated DU-145 prostate cancer cells. Br J Cancer 94:884-890

73. Bradke TM, Hall C, Carper SW, Plopper GE (2008) Phenylboronic acid selectively inhibits human prostate and breast cancer cell migration and decreases viability. Cell Adhesion and. Migration 2: $153-160$

74. Hunt C (1994) Biochemical effects of physiological amounts of dietary boron in animal models. Environ Health Perspect 102(Suppl 7):35-43

75. Armstrong TA, Spears JW (2003) Effect of boron supplementation of pig diets on the production of tumor necrosis factor-a and interferon-g. J Anim Sci 81:2552-2561 
76. Eckhert CD, Rowe RI (1999) Embryonic dysplasia and adult retinal dystrophy in boron-deficient zebrafish. J Trace Element Exp Med 12:213-219

77. Ravindran S, Gao Q, Ramachandran A, Sundivakkam P, Tiruppathi C, et al. (2012) Expression and distribution of grp-78/bip in mineralizing tissues and mesenchymal cells. Histochem Cell Biol 138: $113-125$

78. Wang W, Lian N, Ma Y, Li L, Gallant RC, et al. (2012) Chondrocytic Atf4 regulates osteoblast differentiation and function via Ihh. Development 139:601-611

79. Danciuk TE, Li Y, Koh A, Xiao G, McCauley LK, et al. (2012) The basic helix loop helix transcription factor Twist 1 is a novel regulator of ATF4 in osteoblasts. J Cell Biochem 113:70-79

80. Kroeger H, Mesah C, Ahern K, Gee J, Joseph V, et al. (2012) Induction of endoplasmic reticulum stress genes, $\mathrm{BiP}$ and Chop, in genetic and environmental models of retinal degeneration. Invest Ophthalmol Vis Sci 53:7590-7599

81. Kosmaoglou M, Kanuga N, Aguila M, Garriga P, Cheetham E (2009) A dual role for EDEM1 in the processing of rod opsin. J Cell Sci 122:4465-4472

82. Yue J, Wei W, Lam CMC, Zhao Y-J, Dong M, et al. (2009) CD38/cADPR/Ca2 pathway promotes cell proliferation and delays nerve growth factor-induced differentiation in PC12 cells*. J Biol Chem 284: 29335-29335.

83. Izquierdo JM, Alcalde J, Carrascoso I, Reyes R, Ludena MD (2011) Knockdown of T-cell intracellular antigens triggers cell proliferation, invasion and tumour growth. Biochem J 435:337-344

84. Wei PL, Kuo LJ, Wang W, Lin FY, et al. (2012) Silencing of glucose-regulated protein 78 (GRP78) enhances cell migration through the upregulation of vimentin in hepatocellular carcinoma cells. Ann Surgical Oncol 19:S572-S579

85. Alur M, Nguyen MM, Eggener SE, Jiang F, Dadras SS, et al. (2009) Suppressive roles of calreticulin in prostate cancer growth and metastasis. Am J Pathol 175:882-890
86. So AY-L, de la Fuente E, Walter P, Shuman M, Bernales S (2009) The unfolded protein response during prostate cancer development. Cancer Metastasis Rev 28:219-223

87. O'Neill MA, Warrenfeltz D, Kates K, Pellerin P, Doco T, et al. (1996) Rhamnogalacturonan-II, a pectic polysaccharide in the walls of growing plant cell, forms a dimer that is covalently cross-linked by a borate ester. In vitro conditions for the formation and hydrolysis of the dimer. J Biol Chem 271:2292322930

88. Mitrou PN, Kipnis V, Thiebaut ACM, Reedy J, Subar AF, et al. (2007) Mediterranean dietary pattern and prediction of all-cause mortality in a US population: results from the NIH-AARP Diet and Health Study. Arch Intern Med 167:2461-2468

89. Rainey CJ, Nyquist LA, Christensen RE, Strong PL, Culver D, et al. (1999) Daily boron intake from the American diet. J Am Diet Assoc 99:335-340

90. Song X, Li F, Liu Z, Zhang L, Zhu J, et al. (2011) Boron background value survey of some foodstuffs in 12 provinces of China and boron primary intake estimation of Chinese habitants. Wei Sheng Yan Jiu 40:431-433

91. Wilson KM, Kasperzyk JL, Rider JR, Kenfield S, van Dam RM, et al. (2011) Coffee consumption and prostate cancer risk and progression in the health professionals follow-up study. J Natl Cancer Inst 103:876-884

92. Yan L, Spitznagel EL (2009) Soy consumption and prostate cancer risk in men: a revisit of a meta-analysis. Am J Clin Nutr 89:11551163

93. WHO (1998) Boron, environmental health criteria 204. International Programme on Chemical Safety. World Health Organization, Geneva, pp 61-65

94. Jansen A, Andersen J, Schou JS (1984) Boric acid single dose pharmacokinetics after intravenous administration to man. Arch Toxicol 55:64-67 